


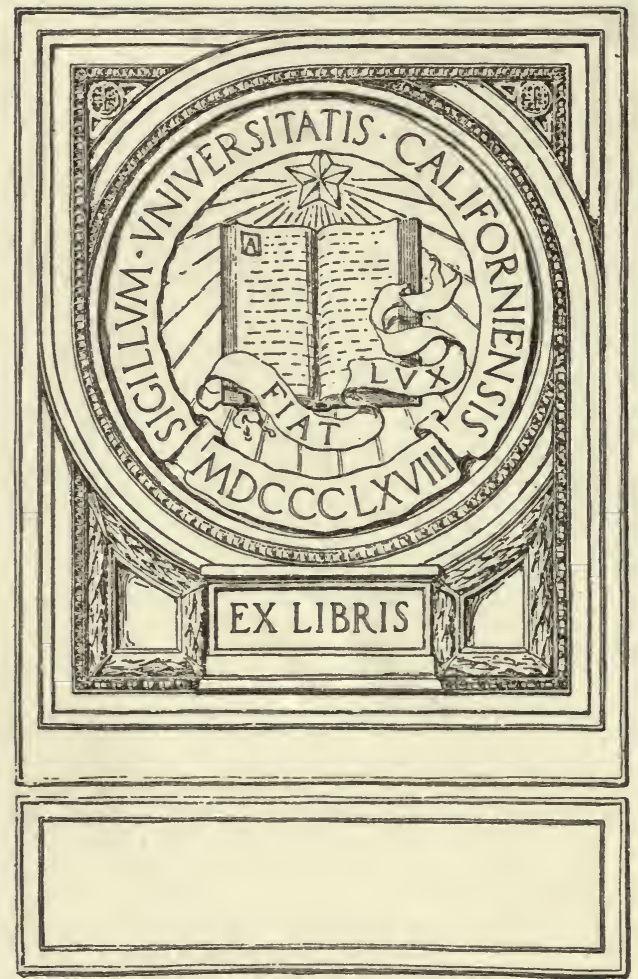



Digitized by the Internet Archive in 2007 with funding from Microsoft Corporation 


U. S. DEPARTMENT OF AGRICULTURE, BUREAU OF CHEMISTRY - BULLETIN No. 97.

H. W. WILEY, Chief of Bureau.

\section{STUDIES ON PEACHES.}

I. COMPILED ANALYSES OF PEACHES.

II. CHANGES IN CHEMICAL COMPOSITION OF THE PEACH DURING GROIVTH AND RIPENING.

III. EFFECT OF STORAGE ON THE COMPOSITION OF PEACHES.

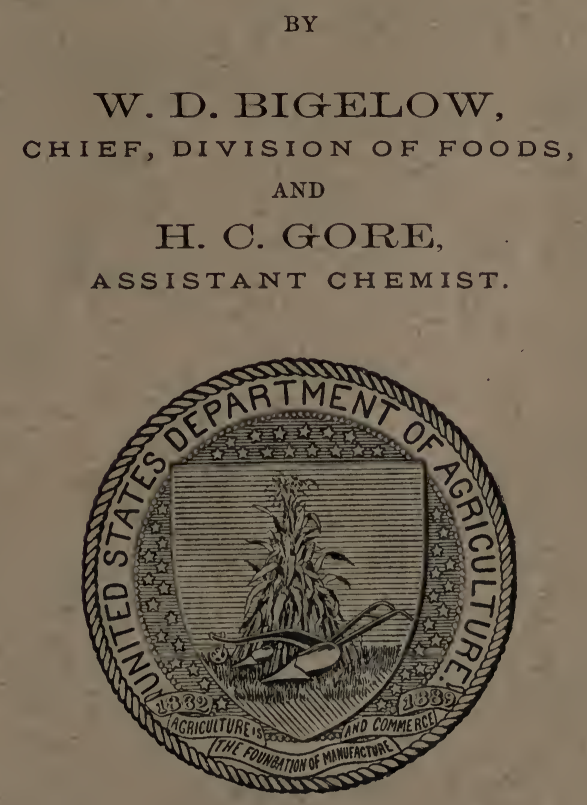

WASHINGTON:

GOVERNMENT PRINTING OFFICE.

1905 . 


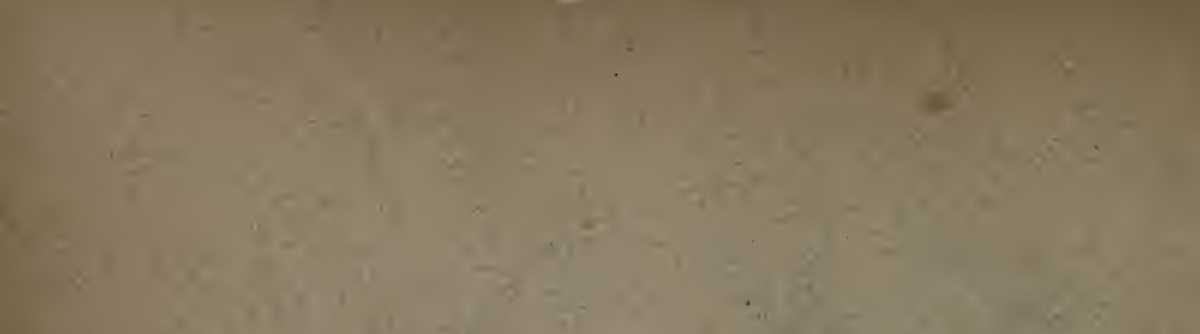

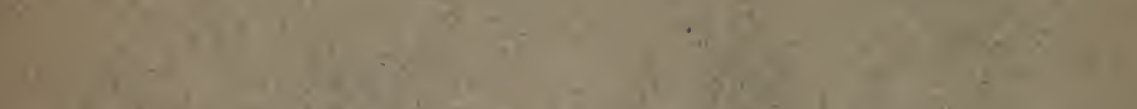

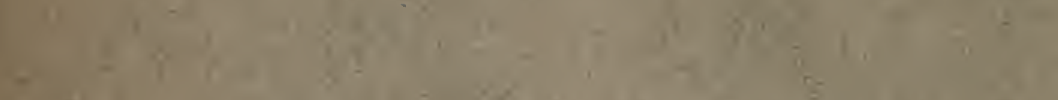

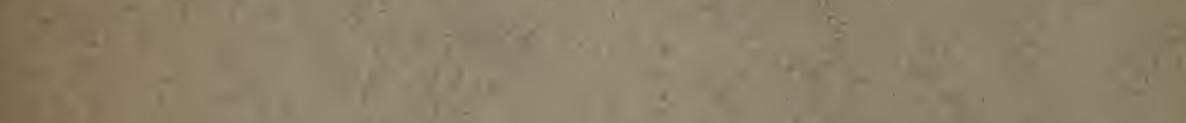

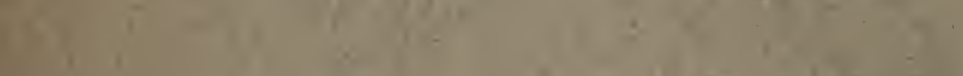

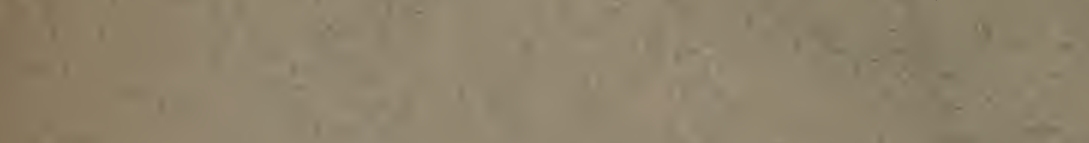

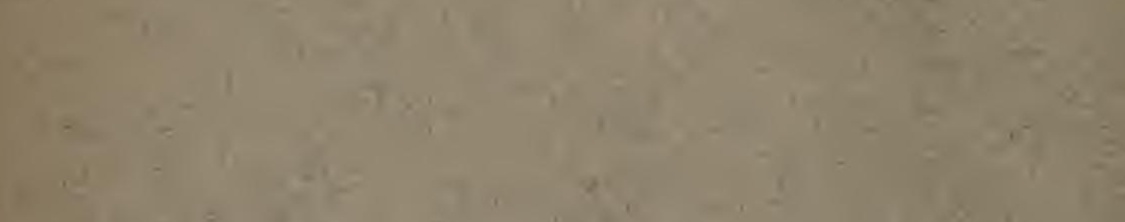

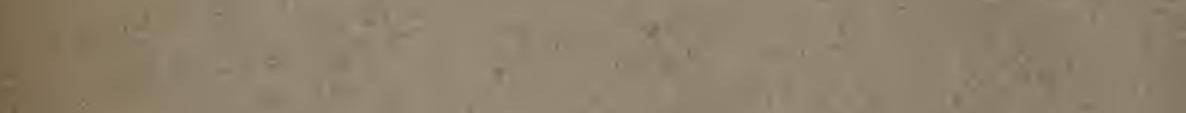

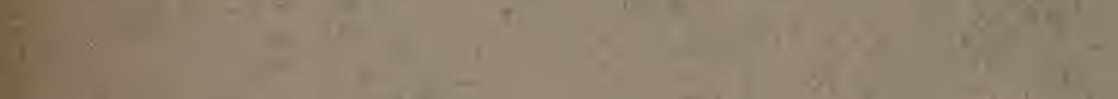

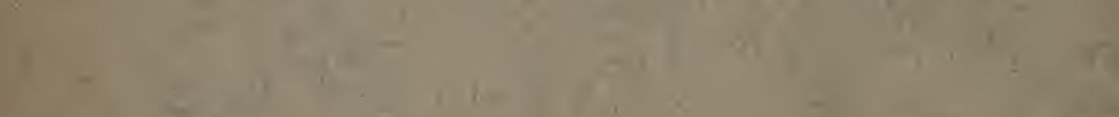

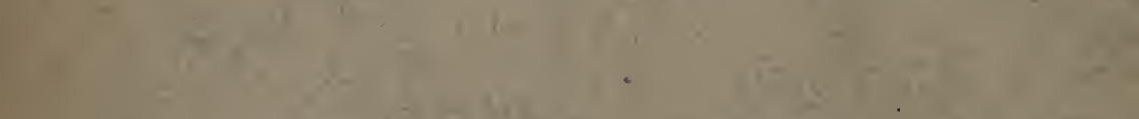

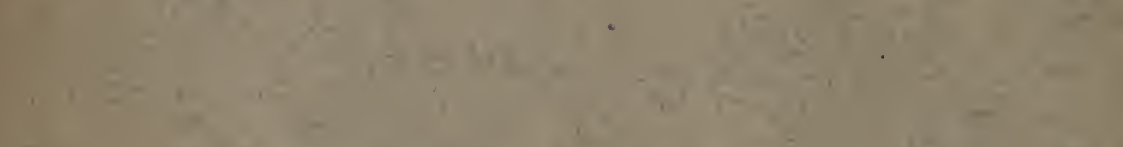

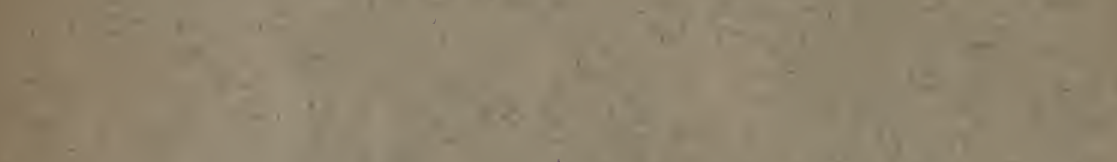

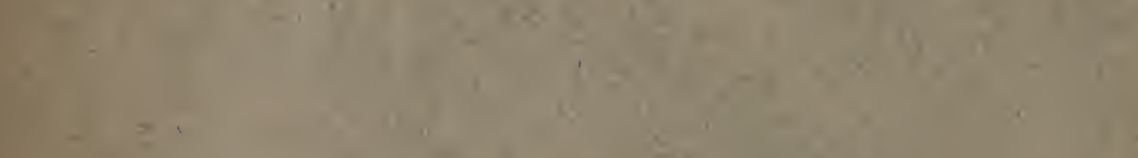

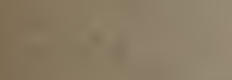

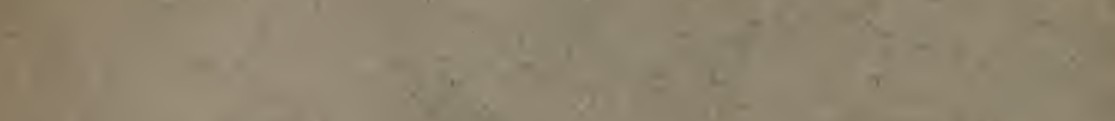

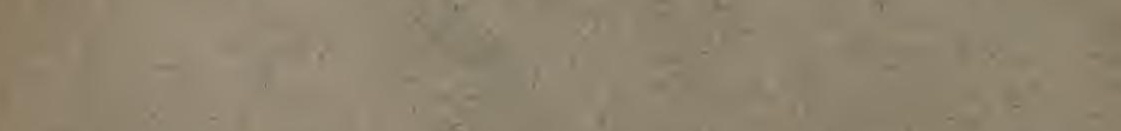

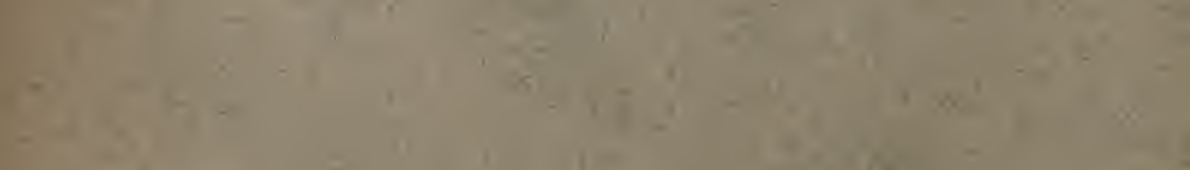

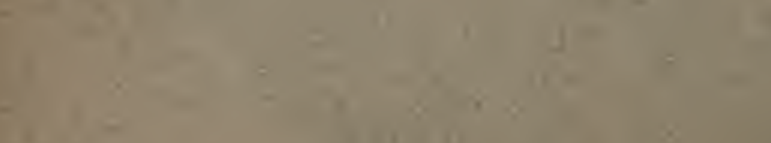

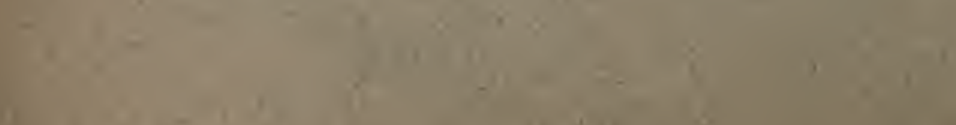

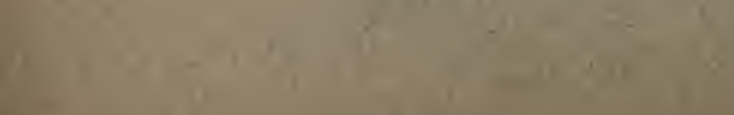

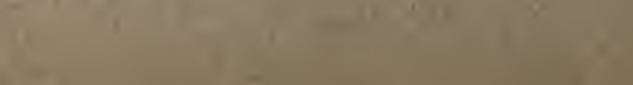




\section{U. S. DEPARTMENT OF AGRICULTURE,}

BUREAU OF CHEMISTRY - BULLETIN No. 97.

H. W. WILEY, Chief of Bureau.

\section{STUDIES ON PEACHES.}

I. COMPILED ANALYSES OF PEACHES.

II. CHANGES IN CHEMICAL COMPOSITION OF THE

PEACH DURING GROWTH AND RIPENING.

III. EFFECT OF STORAGE ON THE COMPOSITION OF PEACHES.

BY

W. D. BIGELOW, CHIEF, DIVISION OF FOODS,

AND

H. C. GORF:

ASSISTANT CHEMIST.

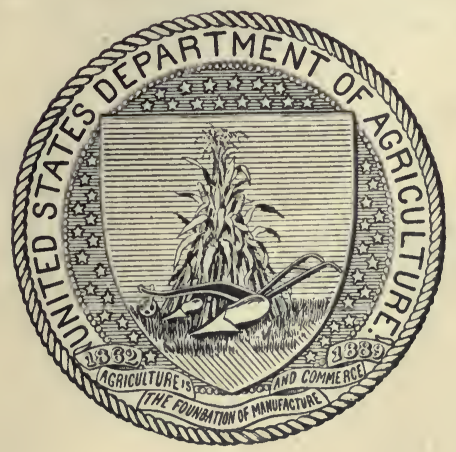

WASHING'TON:

GOVERNMENT PRINTING OFFICE.

1905 . 


\section{LETTER OF TRANSMITTAL.}

\section{U. S. Departhent of Agriculture,}

Bureau of Chemistry,

Washington, D. C., July 5, 1905 .

SiR: I have the honor to transunit for your inspection and approval a manuscript containing the results of a recent study made in the Division of Foods of this Bureau of the changes in chemical composition of peaches during their growth, ripening, and storage. In this study, as in the work on apples recently reported, the office of pomological investigations, Bureau of Plant Industry, has collaborated. The present investigation is a continuation of a series of studies on fruits, beginning with the study of the apple published as Bulletin 94 of this Bureau. The chemical methods employed in the study of the apple have also been applied to the study of the peach. For this work the writers had exceptional opportunities to secure a wide range of varieties of peaches grown under similar and well-known cultural conditions. The varieties were selected and secured by Mr. William A. Taylor, pomologist in charge of field investigations of the Department of Agriculture. The fruit was grown on the farm of Mr. M. B. Waite, at Woodwardville, Md., in the summer of 1904. I recommend that this report be published as Bulletin No. 97 of the Bureau of Chemistry.

Respectfully,

W. D. Bigelow, Acting Chief.

Hon. James WILSON,

Secretary of Agriculture.

2 


\section{CONTENTS.}

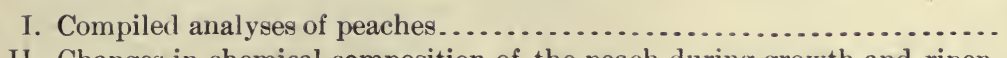

Page.

II. Changes in chemical composition of the peach during growth and ripening.

III. Effect of storage on the composition of peaches 



\section{STUDIES ON PEACHES.}

Very few complete analyses of peaches seem to have been made. The methods for the examination of products of this kind have been greatly improved during recent years and the results of later analyses, for this reason, are much more reliable than earlier ones. Considering the large number of analyses of apples, pears, and some other varieties of fruits that have been published, it is a matter of surprise to note how few peach analyses have been reported. The only published analyses with which the writers are familiar are collected in Table I. From this table it will be noted that of the analyses made according to modern methods only those of Kulisch and Girard are at all complete.

\section{COMPILED ANALYSES OF PEACHES.}

Geiseler $^{a}$ and Lehmann ${ }^{b}$ obtained amygdalin from peach kernels (Kernen), Geiseler finding 3 per cent and Lehmann 2.35 per cent of the glucoside.

Ritthausen ${ }^{c}$ investigated the proteid of peach kernels and found it to be similar to the conglutin in lupines.

Considerable work has been done on the oil from peach kernels, chiefly with regard to its use as an adulterant of almond oil, for which the reader ${ }^{\star}$ is referred to standard works on oils. ${ }^{\prime}$

Bauer $^{e}$ isolated galactose from the sulphuric acid hydrolysis product of peach gum.

Stone ${ }^{f}$ prepared galactose and arabinose from peach gum. Gum from the peach tree, as well as the gum from peaches, yielded the above sugars.

Storer $^{g}$ reported the proximate composition of peach stones as obtained by the Weedne method. Storer later ${ }^{h}$ examined peach stones, using chiefly Lange's method of fusion with caustic potash for the estimation of cellulose. The method yielded a cellulose having a very high content of pentosans (45.23 per cent). The filtrate from the reaction product yielded about 15 per cent of Lange's "lignic acid." Two nitric-acid methods were tried, but not the chlorination method of Cross and Bevan. ${ }^{i}$ Storer concludes that peach stones probably contain a smaller proportion of true cellulose than occurs in various kinds of woods.

a Centrbl., 1840, 11, 403.

b N. Rep. Pharm., 23, 449; Jahresb., 1874, 887.

$c$ J. prakt. Chem., 1882, 26, 440.

$d$ Chemical Technorogy and Analysis of Oils, Fats, and Waxes, Lewkowitsch; Oils, Fats, and Waxes, and their Manufactured Products, Wright and Mitchell, etc.

$e$ Landw. Versuchs-Stat., 1888, 35, 33.

$f$ Am. Chem. J., 1890, 12, 435.

$g$ Bul. Bussey Inst., 1874, 1, 373.

hIbid., 1898, 2, 410.

$i$ Cellulose, p. 95 . 


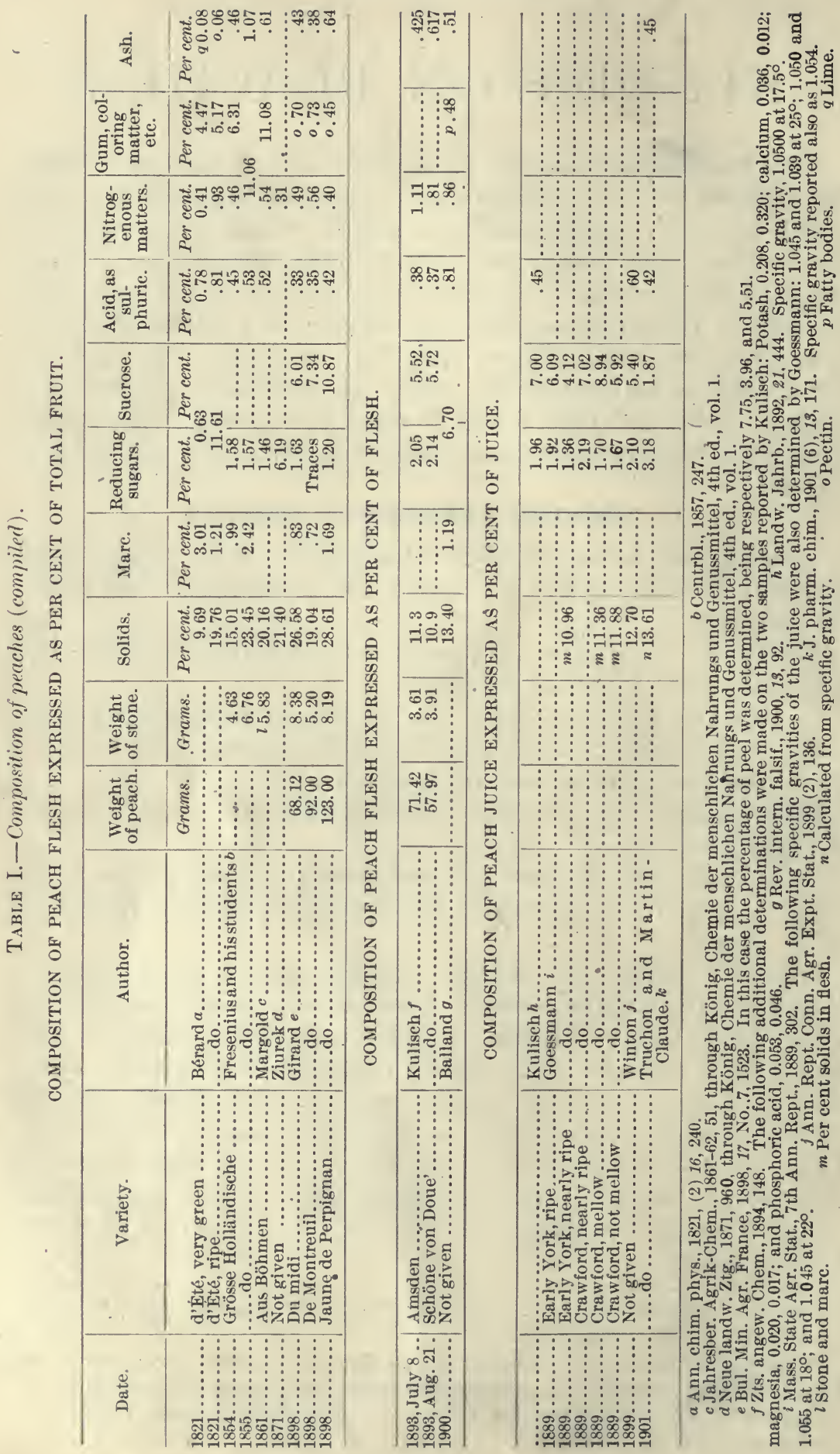




\section{CHANGES IN CHEMICAL COMPOSITION OF THE PEACH DUR- ING GROWTH AND RIPENING.}

The definite stages in the development of the fruit selected for sampling were as follows:

(1) After the June drop.-This period of the life history of the peach was selected as the first time of sampling because of the fact that it is the earliest point at which a sample can be secured of the fruit that will probably mature normally. The fruits which are not going to mature on account of imperfect fertilization or other cause "shatter" or drop off at this time. Before securing the first sample the trees were shaken and a portion of the fruit which appeared to be firmly attached, selected from different sections of the tree, was picked.

(2) When the stone hardens.-The peaches were carefully watched until the time when the stone could only be cut through with difficulty with a knife. The second sample of peaches was then secured.

(3) When market ripe.-Here the fruit is fully developed and almost the full degree of color has been attained. 'The flesh, however, is firm and the fruit will stand shipping. This is the commercial picking time.

(4) When fully ripe.-Here the peach is fully colored and somewhat larger than at the time of market ripeness. The flesh is soft and the fruit so easily bruised by handling that it will not stand shipment.

The examinations made in the Bureau of Chemistry were performed at three, and when possible at four, intervals of the life history of the peach. In selecting all the samples the fruits were gathered from all sides of the tree and from the inner as well as the outer portions. The successive samples of each variety were taken from the same tree. An attempt was made to secure a sample of such size that its composition would represent the composition of the average peach upon the tree at that time. Of the first samples picked about a hundred peaches were employed. Of the last samples, when the peach was fully ripe, about twenty peaches of each variety were secured for each sample. The fruit was gathered by one of the writers on the morning of the same day on which the analysis was begun.

The varieties of peaches employed were 'Triumph, Rivers (or Early Rivers), Early Crawford, Stump (or Stump the World), Elberta, Orange Smock, and Heath Cling (or White Heath). The following descriptions of the several varieties were furnished by Mr. W. A. Taylor, of the Bureau of Plant Industry:

TRIUMPH,

Size medium; flattened, globular, often angular. Surface uneven; greenish yellow, washed with mixed red and marked with vivid broken stripes of dark purplish red; dots rare, pink; down very abundant, short, loose; cavity wide, oval, deep, abrupt, pink; suture generally shallow, extending from cavity to apex; apex a sharp point extending above suture walls; skin thick and leathery, but soft; stone of medium 
size, oval, free; flesh yellow, stained with red, firm, somewhat fibrous, juicy; mild subacid; quality good; season very early. A soft-fleshed semi-cling, little esteemed except for its extreme earliness. Chiefly used for eating out of hand or for slicing.

\section{RIVERS (SYN. EARLY RIVERS).}

Size small to medium; roundish, bulged; surface soft, velvety; creamy white with blush and splashes of crimson; dots minute, pink; down short, adherent; cavity large, deep, abrupt, green; suture distinct, deep at cavity and apex; apex a small point within the suture; skin medium tender, slightly tenacious; stone oval, of medium size, pale, semi-cling; flesh greenish white, tender, melting, juicy; subacid, pleasant; good to very good when fully ripe. Season second early. Very delicate fleshed, soft, easily bruised, and chiefly prized for its earliness and productiveness.

\section{EARLY CRAWFORD.}

Size large, roundish, oval, often angular; surface smooth, yellow with a rich crimson blush on exposed surface; dots rare; down abundant, loose; cavity large, deep, of gradual slope, red; suture distinct, deep at cavity and apex; apex a small point often recurved; skin thick, tender; stone large, oval, free; flesh yellow, stained red at stone, tender, melting, juicy; subacid, rich; very good; though formerly considered an early sort it is now a midseason variety, being preceded by a large number of varieties of more recent origin. Highly esteemed for use in the fresh state and for canning.

\section{STUMP (SYN. STUMP THE WORLD).}

Size medium; roundish oblong, sometimes unequal; surface moderately smooth, greenish white, with blush of dark crimson on exposed surface; dots minute, crimson; down short, thick, persistent; cavity regular, deep, abrupt or gradual, red; suture shallow, except at cavity. Apex a small double point, elevated slightly above the general surface of the fruit; skin thick, tenacious; stone large, oval, free; flesh white or greenish white; stained red at stone, tender, melting, moderately juicy; subacid, sprightly, good; season shortly after Early Crawford. Highly esteemed for canning.

\section{ELBERTA.}

Size large, roundish oval; surface medium soft, velvety; yellow, blushed, marbled, and faintly striped with bright crimson; dots yellow on red; down short, adherent; cavity regular, large, deep, gradual, red; suture medium, shallow, except at cavity and apex; apex a small point in suture; skin medium thick, tenacious; stone large, oval, free; flesh yellow, stained red at stone; meaty, tender, moderately juicy, subacid, good. Season about with Stump, shortly after Early Crawford. Chiefly esteemed for its uniform large size, bright color, and good shipping quality. A fairly good canner, but not highly esteemed as a dessert peach. The most popular commercial variety at the present time in the Middle States and southern peach districts.

ORANGE SMOCK.

Size medium; roundish oval, slightly unequal; light yellow, with splashes of red on exposed side; down long, abundant, persistent; cavity medium, oval, of medium depth, abrupt; suture of medium and uniform depth; apex small, with black tip within suture; skin thick, harsh; stone large, broad, thick, free; flesh light yellow, red at stone, melting; moderately juicy, tart, brisk, pleasant, good; season late. One of the best varieties of the Smock type, all of which are rather dry-fleshed and are used for canning and drying rather than in the fresh state. 
HEATH CLING (SYN. WHITE HEATH).

Size medium to large; oblong-oval, surface smooth, creamy-white, often with a delicate crimson blush on exposed side; dots rare; down short; cavity regular, small, abrupt; suture medium, extending from cavity to apex; apex prominent; skin thick, tenacious; stone medium, cling; flesh ( reamy-white, firm, melting, juicy; sweet, rich; very good; season late. Very popular for canning and preserving on account of its firm flesh and fine flavor.

The cultural data, as furnished by Mr. S. H. Fulton, assistant pomologist, Bureau of Plant Industry, are as follows:

Trees 6 years old. Soil medium sandy loam. In nursery stock two years previous to planting. Orchard has been thoroughly plowed and well cultivated annually, cultivation continuing up to about August 1 to 15.

Sweet potatoes were planted the first two years, well fertilized and manured. Crimson clover planted in 1902, plowed under in May, 1903, crop very large, causing unusual growth of trees.

Trees sprayed with crude oil and water, spring of 1901 and 1902. Lime-sulphursalt used in 1903 and 1904.

The crop this year (1904) was very heavy. The season was abnormal. For six weeks prior to August 10 the atmosphere was very humid, resulting in the ruin of all peaches ripening up to that date. About August 20 the season became abnormally dry, no rain falling throughout the ripening period of all the later varieties. In comparing the ripening of the early and late peaches with each other, therefore, the varying climatic conditions to which the two classes were subjected must be taken into consideration.

The fruits of the first two pickings were examined microscopically for starch. No starch was found in the embryo or in the stone, and none in the flesh with the exception of a thin layer of granules just under the epidermis of the fruit. The specimens which apparently had the largest amount of starch were examined quantitatively and 0.1 per cent found to be present. This amount is of course negligible and no further determinations of ștarch were made.

The changes in composition of growing fruits may be expressed in two ways: First, the percentage composition of the fruit at various stages of growth, showing the change in composition of the substance, and hence in nature as it progresses; second, the actual weight of solids, water, sugar, starch, proteids, etc., in an individual of the species under examination. For example, it is interesting, on the one hand, to note the changes in percentage composition which occur as peaches progress from the green to the ripe stage; on the other hand, the actual weights of each ingredient present in a single peach at various stages of the life history of the fruit are of still greater interest and throw more light on the changes in chemical composition.

6041-No. 97-05-2 
STUDIES ON PEACHES.

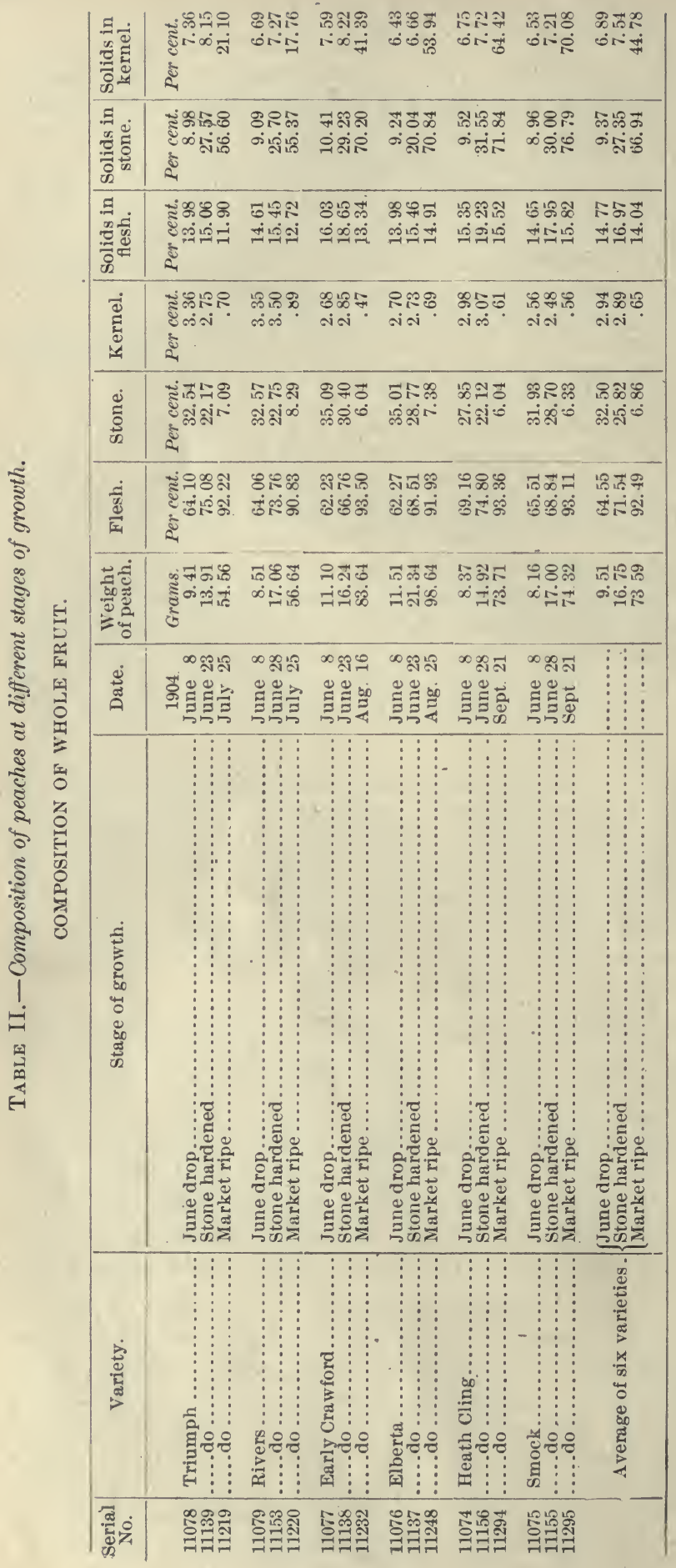


CHANGES IN COMPOSITION DURING GROWTH.

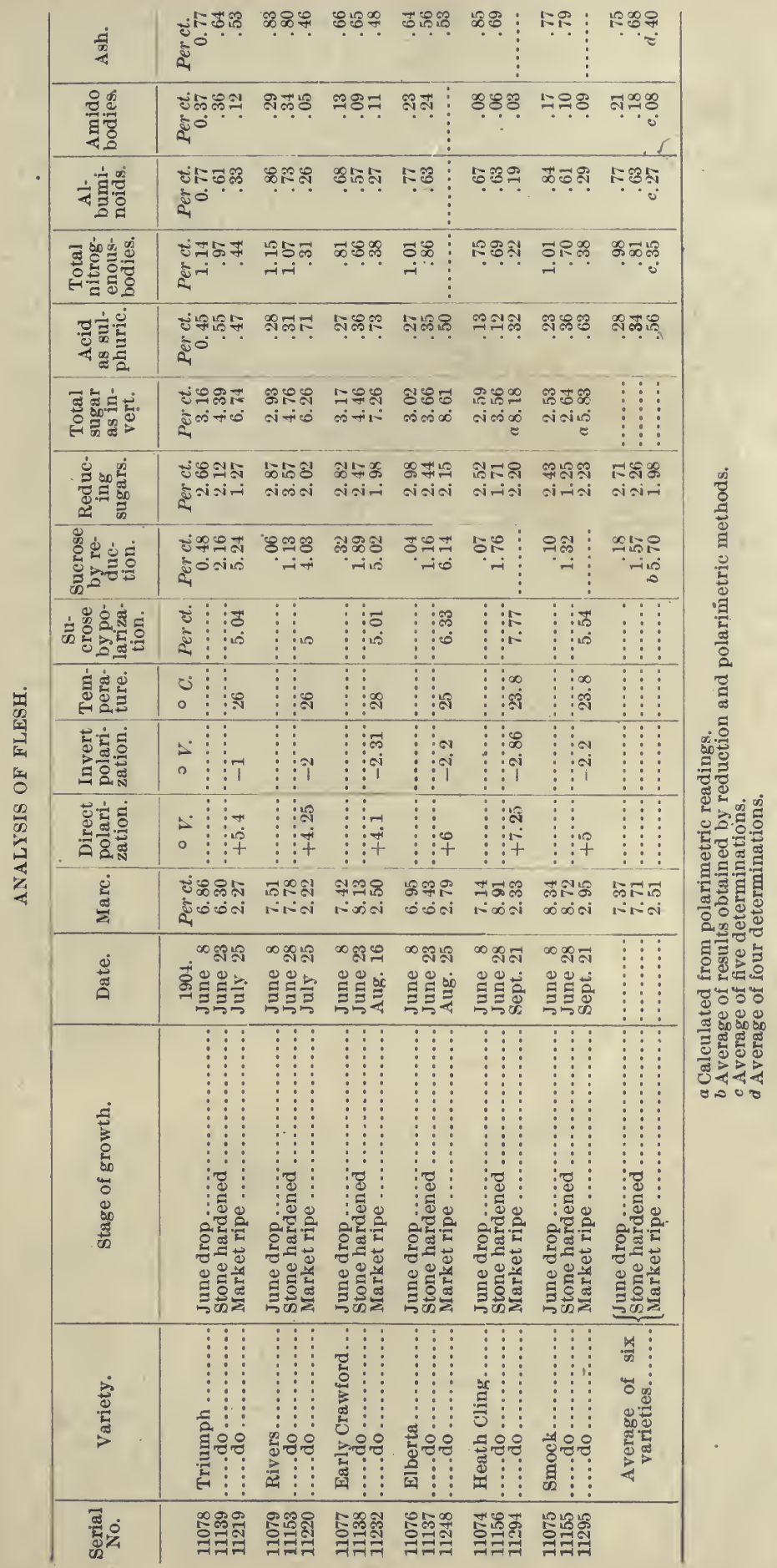


In Table II there is given in detail the percentage composition of six varieties of peaches at three stages of their life history ${ }^{a},-\mathrm{i}$. e., the time of the June drop, when the peach is small and very green; the period at which the stone hardened, or two to three weeks later; and the period at which the peaches were market ripe, i. e., well colored but firm. In two cases (Elberta and Smock) the peaches were also examined at a fourth stage, when fully ripe. On account of the difficulty of keeping samples on the trees until they became fully ripe the other varieties were not examined at this last stage. In addition to the dropping of the peaches, which would normally take place, the orchards were somewhat afflicted with scab, which increased the tendency of the peaches to drop. It is regretted that samples were not taken between the second and third periods of the life history of the peaches.

The change in composition between the time of the hardening of the stone and the time of market ripeness is very great, as will be seen by consulting Table II. During this period the weight of the peaches increased more than fourfold. The proportion of flesh to stone increased about five times and the composition of the flesh itself went through much greater changes than occurred earlier in the life history of the fruit. The examination of samples at more frequent intervals would indicate more exactly the period in the life history of the peach at which these changes begin and at which they are greatest, and for that reason would be very valuable. The results here given, however, are believed to be of value for the purpose of marking out the boundaries within which certain changes occur and limiting the field within which further investigations of this nature can be carried on with profit. A comparatively small amount of work will now be required to accumulate the details necessary to make our knowledge of the life history of the peach much more complete than it is at present.

Between the time of the June drop and the time of market ripeness the peaches increased in weight nearly eight times, from 9.51 to 73.59 grams per peach. During the same time the per cent of flesh in the peach increased less than one-half, from 64.55 to 92.49 ; while the per cent of the stone decreased from 32.5 to 6.86 , and that of the kernel from 2.94 to 0.65 per cent.

The percentage of solids of the flesh ${ }^{b}$ remains fairly constant during the life history of the peach; that is, the increase in solids is fairly

$a$ See pages 10, 11 .

$b$ In Table II, and wherever else percentages are given in this bulletin, the calculations are made as follows: The percentages of flesh, of stone, and of kernel are based upon the weight of the whole peach. The percentages of solids in flesh, of solids in stone, and of solids in kernel are based upon the weight of the flesh, the stone, and the kernel, respectively. The percentages of the several constituents of the flesh are based upon the weight of the flesh. 
proportional to the increase in water. ${ }^{a}$ This is shown by the fact that the percentage of solids did not greatly change from the time of the June drop to the period at which the peaches were considered market ripe. On the other hand, during the same period the stone changed greatly in its nature. As it became harder and more mature the percentage of water materially decreased and the percentage of solids increased from 9.37 at the period of the June drop to 66.94 when the peaches were market ripe. The solid content of the kernel increased from 6.89 per cent at the time of the June drop to 44.78 per cent when the peaches were market ripe. At the same time it should be noted that the percentage of solids in the kernel did not materially increase until after the hardening of the stone.

The percentage of marc remained fairly constant, showing, however, a slight increase somewhat commensurate with that of the increase in solids until the hardening of the stone. After that, however, the percentage of marc greatly decreased, until at the time of market ripeness it was about one-third as great as at the earlier stages in the life history of the peach. The term "marc" is here used in its usual significance to apply to the total insoluble matter of the flesh of the peach, including the skin. It was determined by a thorough exhaustion with water by the method described in the previous work with apples. ${ }^{b}$

The percentage of reducing sugar's varied less than was the case with the other substances just considered. A distinct tendency to decrease, however, is evident. This decrease is also true of the percentage of nitrogenous substances in all their forms calculated as total protein, albuminoids and amido bodies, and also of ash. On the other hand, the percentage of sucrose and of acids increased from the beginning to the end of the experiment.

The average composition at market ripeness of seven varieties of peaches, six of which are included in Table II, is as follows:

Composition of whole peach.

Grams.

71. 66

Weight (per peach)

Per cent.

92.31

Flesh

Stone

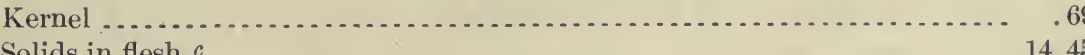

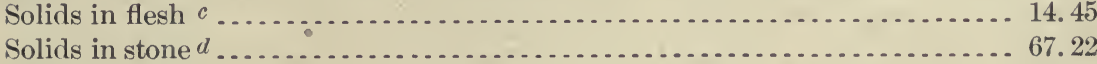

Solids in embryo $c$................................................ 47.50

$a$ Also true in the case of apples. U. S. Dept. Agr., Bureau of Chemistry Bul. 94, Studies on Apples.

$b$ Loc. cit.

$c$ Dried in vacuo at $70^{\circ} \mathrm{C}$.

$a^{i}$ Dried at $100^{\circ} \mathrm{C}$. 


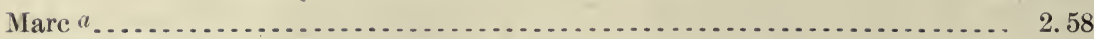

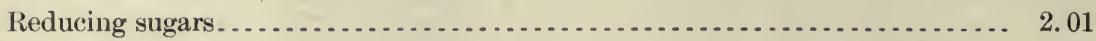

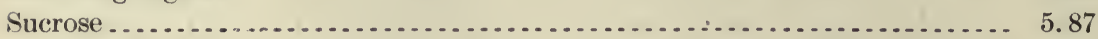

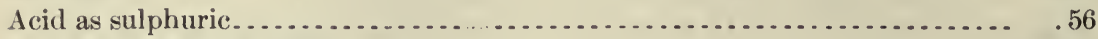

Total nitrogenous bodies................................... ${ }^{b} .35$

Albuminoids $c$.............................................. ${ }^{b} .27$

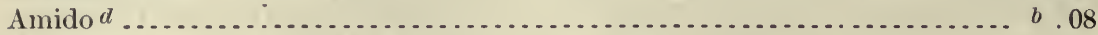

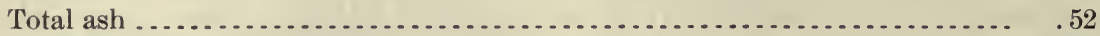

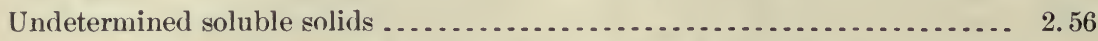

As previously stated, four of the varieties of peaches examined did not remain in good condition until they reached full ripeness. . In some cases this was due to the fact that the peaches were early affected with Monilia, or brown rot, while in other cases they either fell from the tree, or the number of peaches that could have been obtained in the fully ripe state was insufficient for analysis. For this reason samples of fully ripe peaches of those varieties could not be examined. It must be understood of course that all of the samples examined reached the state of maturity indicated in the tables before picking from the trees, fifteen peaches being picked for each sample.

Two of the varieties under examination (Elberta and Smock), as before stated, did remain on the tree until fully ripe, and one other variety (Stump) was obtained both at the market-ripe and fully-ripe stages. The composition of these three varieties at the two stages mentioned is given in Table III.

TABLE III.-Composition of peaches at market ripeness and at full ripeness. COMPOSITION OF WHOLE FRUIT:

MARKET RIPE.

\begin{tabular}{|c|c|c|c|c|c|c|c|c|c|}
\hline \multirow{2}{*}{$\begin{array}{l}\text { Serial } \\
\text { No. }\end{array}$} & \multirow{2}{*}{ Variety. } & \multirow{2}{*}{ Date. } & \multirow{2}{*}{$\begin{array}{l}\text { Weight } \\
\text { of perch. }\end{array}$} & \multirow{2}{*}{ Flesh. } & \multirow{2}{*}{ Stone. } & \multirow{2}{*}{ Kernel. } & \multicolumn{3}{|c|}{ Solids in- } \\
\hline & & & & & & & Flesh. & Stone. & Kernel. \\
\hline $\begin{array}{l}11248 \\
11295 \\
11249\end{array}$ & 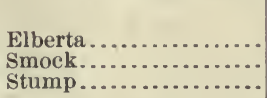 & $\begin{array}{c}\text { 1904. } \\
\text { Aug. } 25 \\
\text { Sept. } 21 \\
\text { Aug. } 25\end{array}$ & $\begin{array}{r}\text { Grams. } \\
98.64 \\
74.32 \\
61.53\end{array}$ & $\begin{array}{l}\text { Per ct. } \\
91.93 \\
93.11 \\
91.23\end{array}$ & $\begin{array}{r}\text { Per ct. } \\
7.38 \\
6.33 \\
8.00\end{array}$ & $\begin{array}{r}\text { Per ct. } \\
0.69 \\
.56 \\
.76\end{array}$ & $\begin{array}{l}\text { Per ct. } \\
14.91 \\
15.82 \\
16.95\end{array}$ & $\begin{array}{l}\text { Per ct. } \\
70.84 \\
76.79 \\
68.90\end{array}$ & $\begin{array}{r}\text { Per ct. } \\
53.94 \\
70.08 \\
63.78\end{array}$ \\
\hline
\end{tabular}

FULL RIPE.

\begin{tabular}{l|r|r|r|r|r|r|r|r|r}
\hline 11258 & Elberta................ & A ug. 30 & 98.92 & 91.30 & 8.06 & 0.63 & 15.23 & 74.48 & 59.00 \\
11298 & Smock................. & Sept. 26 & 86.67 & 92.88 & 6.53 & .58 & 15.78 & 76.74 & 69.10 \\
11250 & Stump................ & Aug. 27 & 69.60 & 91.60 & 7.75 & .64 & 17.52 & 65.16 & 57.65 \\
\hline
\end{tabular}

COMPARISON OF THE TWO STAGES.

\begin{tabular}{|c|c|c|c|c|c|c|c|}
\hline 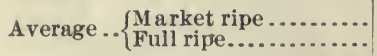 & $\begin{array}{l}76.13 \\
85.06\end{array}$ & $\begin{array}{l}92.09 \\
91.93\end{array}$ & $\begin{array}{l}7.24 \\
7.45\end{array}$ & $\begin{array}{r}0.67 \\
.62\end{array}$ & $\begin{array}{l}15.89 \\
16.18\end{array}$ & $\begin{array}{l}72.18 \\
72.13\end{array}$ & $\begin{array}{l}62.60 \\
61.93\end{array}$ \\
\hline $\begin{array}{l}\text { } a \text { Dried in vacuo at } 70^{\circ} \mathrm{C} \text {. } \\
b \text { Average of five determinations. }\end{array}$ & & $\begin{array}{l}c \mathrm{Ni} \\
d \mathrm{Ni}\end{array}$ & gen & atzer $x$ & ethod & $\begin{array}{l}6.25) \text {. } \\
4.25) \text {. }\end{array}$ & \\
\hline
\end{tabular}


TABLE III.-Composition of peaches at market ripeness and at full ripeness-Continued.

ANALYSIS OF FLESH.

MARKET RIPE.

\begin{tabular}{|c|c|c|c|c|c|c|c|c|c|c|c|c|}
\hline \multirow[b]{2}{*}{$\begin{array}{c}\text { Serial } \\
\text { No. }\end{array}$} & \multirow[b]{2}{*}{ Variety. } & \multirow[b]{2}{*}{ Date. } & \multirow[b]{2}{*}{ Marc. } & \multirow[b]{2}{*}{$\begin{array}{l}\text { Reduc- } \\
\text { ing } \\
\text { sugar. }\end{array}$} & \multirow{2}{*}{ 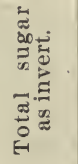 } & \multirow{2}{*}{ 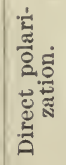 } & \multirow{2}{*}{ 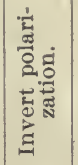 } & \multirow{2}{*}{ 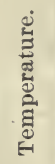 } & \multicolumn{2}{|c|}{ Sucrose. } & \multirow{2}{*}{ 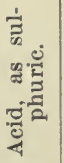 } & \multirow[b]{2}{*}{ Ash. } \\
\hline & & & & & & & & & 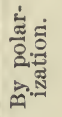 & 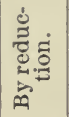 & & \\
\hline
\end{tabular}

FULL RIPE.

\begin{tabular}{|c|c|c|c|c|c|c|c|c|c|c|c|c|}
\hline 11298 & Smock c...... & Sept. 26 & 2.69 & 2.76 & b 7.65 & 6.6 & 2.86 & 23.8 & 7.27 & & .53 & ...... \\
\hline 11250 & Stump ........ & Aug. 27 & 2.27 & 2.19 & 10.14 & 7.3 & 2.42 & 27.4 & 7.57 & 7.49 & .46 & .60 \\
\hline
\end{tabular}

COMPARISON OF THE TWO STAGES.

\begin{tabular}{|c|c|c|c|c|c|c|c|c|c|c|}
\hline Average..$\left\{\begin{array}{l}\text { Market ripe. } \\
\text { Full ripe }\end{array}\right.$ & $\begin{array}{l}2.91 \\
2.30\end{array}$ & $\begin{array}{l}2.20 \\
2.27\end{array}$ & $\begin{array}{r}7.97 \\
9.13 \\
.\end{array}$ & an. & an & (a) & (.... & $\begin{array}{l}d 6.23 \\
d 7.36\end{array}$ & $\begin{array}{r}0.53 \\
.48\end{array}$ & $\begin{array}{r}0.57 \\
.55\end{array}$ \\
\hline
\end{tabular}

$a$ Total nitrogenous bodies, 0.38 ; albuminoids, 0.29 ; amido bodies, 0.09 .

$b$ Calculated from polarimetric readings.

c Total nitrogenous bodies, 0.35; a ibuminoids, 0.29 ; amido bodies, 0.06 .

$d$ Average both by reduction and polarization methods except when results by polarimetric method alone were obtained.

The change in composition between the period of market ripeness and the period of full ripeness was much less than that which occurred between the time of the hardening of the stone and the time of market ripeness. In all cases the weight per peach increased to some extent during this period, the increase in weight being 8.93 grams per peach, nearly 12 per cent of the weight of the peach at the time of market ripeness. It is therefore apparent that on account of this increase in weight peaches should be allowed to remain on the tree as long as possible without sacrifice to their keeping and shipping qualities.

During this time the percentage of flesh, stone, and kernel did not greatly change, although a distinct tendency toward growth and thickening and an increase of weight of the stone was apparent. The percentage of solids in flesh and stone is also fairly constant. At the same time it may be noted that there is a distinct though slight increase in the percentage of solids in the flesh, which indicates that the increase in weight is not due to a mere increase in water. This fact is borne out by the increase in the percentage of sugar. During this period the percentage of marc and acids decreases to some extent. . Owing to the relative uniformity of the percentage of solids at the various stages of growth, a much clearer idea of the composition of the water-free material can be obtained from the composition of the total flesh of the 
peach than with many substances in which the proportion of water varies through wide limits. At the same time it is believed that the relations between the various ingredients of the solids of the peach flesh can be shown much more clearly by its composition on the waterfree basis than by its total composition. For this reason the analysis of the peach flesh is given in Tables IV and V on the basis of total solids. On the whole the composition of the peaches on the water-free basis permits of no conclusions that have not already been drawn from the composition of the original substance of the peach flesh. The reasons for such conclusions, however, are emphasized and pointed out more clearly by the data given in Tables IV and V.

TABLE IV.-Analyses of peach flesh.

[Percentage of total solids.]

\begin{tabular}{|c|c|c|c|c|c|c|c|c|c|c|c|c|}
\hline $\begin{array}{c}\text { Serial } \\
\text { No. }\end{array}$ & Variety. & Stage of growth. & Date. & 岕 & 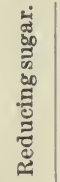 & 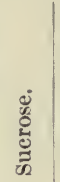 & 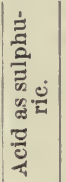 & 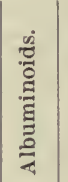 & 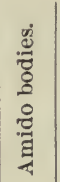 & 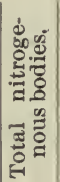 & 安 & 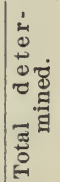 \\
\hline $\begin{array}{l}11078 \\
11139 \\
11219\end{array}$ & $\begin{array}{l}\text { Triumph . } \\
\ldots \ldots \text {..do } \ldots . . . \\
\ldots \ldots \text {. do .... }\end{array}$ & & $\begin{array}{l}1904 . \\
\text { June } 8 \\
\text { June } 23 \\
\text { July } 25\end{array}$ & $\begin{array}{l}49.07 \\
41.84 \\
19.08\end{array}$ & $\begin{array}{l}19.03 \\
14.08 \\
10.67\end{array}$ & $\begin{array}{r}3.43 \\
14.34 \\
43.03\end{array}$ & $\begin{array}{l}3.19 \\
3.68 \\
3.95\end{array}$ & $\begin{array}{l}5.50 \\
4.07 \\
2.73\end{array}$ & $\begin{array}{l}2.65 \\
2.37 \\
1.00\end{array}$ & $\begin{array}{l}8.15 \\
6.44 \\
3.73\end{array}$ & $\begin{array}{l}5.51 \\
4.25 \\
4.45\end{array}$ & $\begin{array}{l}88.38 \\
84.63 \\
84.91\end{array}$ \\
\hline $\begin{array}{l}11079 \\
11153 \\
11220\end{array}$ & ..... do.... & & $\begin{array}{l}\text { June } 8 \\
\text { June } 28 \\
\text { July } 25\end{array}$ & $\begin{array}{l}51.40 \\
50.36 \\
17.45\end{array}$ & & $\begin{array}{r}.41 \\
7.31 \\
35.46\end{array}$ & $\begin{array}{l}1.90 \\
2.03 \\
5.56\end{array}$ & $\begin{array}{l}5.86 \\
4.73 \\
2.07\end{array}$ & $\begin{array}{r}2.01 \\
2.17 \\
.40\end{array}$ & $\begin{array}{l}7.86 \\
6.91 \\
2.47\end{array}$ & $\begin{array}{l}5.68 \\
5.18 \\
3.62\end{array}$ & $\begin{array}{l}91.9 \\
80 .\end{array}$ \\
\hline & $\begin{array}{l}\text { Early } \mathrm{C} \\
\text {.....do. }\end{array}$ & & $\begin{array}{l}\text { June } 8 \\
\text { June } 23 \\
\text { Aug. } 16\end{array}$ & $\begin{array}{l}46.29 \\
43.59 \\
18.74\end{array}$ & & $\begin{array}{r}2.00 \\
10.13 \\
37.64\end{array}$ & $\begin{array}{l}1.68 \\
1.95 \\
5.47\end{array}$ & $\begin{array}{l}4.25 \\
3.05 \\
2.02\end{array}$ & $\begin{array}{l}.82 \\
.48 \\
.80\end{array}$ & $\begin{array}{l}5.07 \\
3.53 \\
2.81\end{array}$ & $\begin{array}{l}4.12 \\
3.49 \\
3.60\end{array}$ & 76.6 \\
\hline $\begin{array}{l}11076 \\
11137 \\
11248\end{array}$ & Elber & & $\begin{array}{l}\text { June } 8 \\
\text { June } 23 \\
\text { Aug. } 25\end{array}$ & $\begin{array}{l}49.71 \\
41.60 \\
18.71\end{array}$ & $\begin{array}{l}21.32 \\
15.78 \\
14.42\end{array}$ & $\begin{array}{r}.29 \\
7.50 \\
41.85\end{array}$ & $\begin{array}{l}1.96 \\
2.25 \\
3.34\end{array}$ & $\begin{array}{r}5.54 \\
4.05 \\
\ldots . .\end{array}$ & $\begin{array}{l}1.67 \\
1.54\end{array}$ & $\begin{array}{l}7.22 \\
5.58\end{array}$ & $\begin{array}{l}4.58 \\
3.62 \\
3.56\end{array}$ & $\begin{array}{l}85.0 \\
76.3 \\
\ldots . .\end{array}$ \\
\hline $\begin{array}{l}11075 \\
11155 \\
11295\end{array}$ & ......do ............ & & $\begin{array}{l}\text { June } 8 \\
\text { June } 28 \\
\text { Sept. } 21\end{array}$ & $\begin{array}{l}56.92 \\
48.58 \\
18.65\end{array}$ & $\begin{array}{r}16.59 \\
6.96 \\
14.10\end{array}$ & $\begin{array}{r}.65 \\
7.35 \\
35.02\end{array}$ & $\begin{array}{l}1.54 \\
2.02 \\
3.95\end{array}$ & $\begin{array}{l}5.76 \\
3.42 \\
1.86\end{array}$ & $\begin{array}{r}1.16 \\
.55 \\
.54\end{array}$ & $\begin{array}{l}6.92 \\
3.96 \\
2.40\end{array}$ & $\begin{array}{r}5.26 \\
4.40 \\
\ldots \ldots\end{array}$ & $\begin{array}{l}87.88 \\
73.2 \\
\ldots . .\end{array}$ \\
\hline $\begin{array}{l}11074 \\
11156 \\
11294\end{array}$ & $\begin{array}{c}\text { Heath } \mathrm{Cl} \\
\ldots \ldots \text { do } . . . \\
\ldots . . \text {. do } . . .\end{array}$ & $\begin{array}{l}\text { June drop.... } \\
\text { Stone hardene } \\
\text { Market ripe... } \\
\left\{\begin{array}{l}\text { June drop...... } \\
\text { Stone hardene } \\
\text { Market ripe... }\end{array}\right.\end{array}$ & $\begin{array}{l}\text { June } 8 \\
\text { June } 28 \\
\text { Sept. } 21\end{array}$ & $\begin{array}{l}46.52 \\
46.34 \\
15.01 \\
49.99 \\
45.39 \\
17.94\end{array}$ & \begin{tabular}{r|}
16.42 \\
8.89 \\
14.18 \\
18.43 \\
13.68 \\
14.02
\end{tabular} & $\begin{array}{r}.46 \\
9.15 \\
50.07\end{array}$ & $\begin{array}{l}1.52 \\
1.68 \\
2.09 \\
1.95 \\
2.27 \\
4.06\end{array}$ & $\begin{array}{r}4.36 \\
3.25 \\
1.21 \\
5.21 \\
3.76 \\
a 1.88\end{array}$ & $\begin{array}{r}.50 \\
.33 \\
.22 \\
1.47 \\
1.24 \\
a .59\end{array}$ & $\begin{array}{r}4.86 \\
3.58 \\
1.42 \\
6.68 \\
5.00 \\
2.57\end{array}$ & $\begin{array}{r}5.54 \\
4.16 \\
\cdots \ldots \\
5.12 \\
4.18 \\
b 3.81\end{array}$ & $\begin{array}{l}75.32 \\
73.80 \\
\cdots \ldots\end{array}$ \\
\hline
\end{tabular}

a Average of five determinations.

b Average of four determinations.

It is apparent that the nature of the fruit in the ripe stage is widely different from that at the beginning of the study. At the earliest stage at which the fruit was examined the solids of the flesh were practically 50 per cent marc and less than 20 per cent were sugars, whereas at the period of market ripeness less than 18 per cent were marc and nearly 55 per cent were sugars. 
TABLE V.-Composition of the flesh of peaches at market ripeness and at full ripeness.

[Percentage of total solids.]

MARKET RIPE.

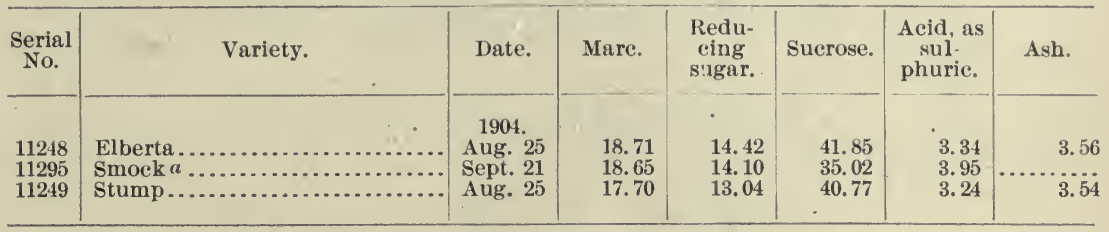

FULL RIPE.

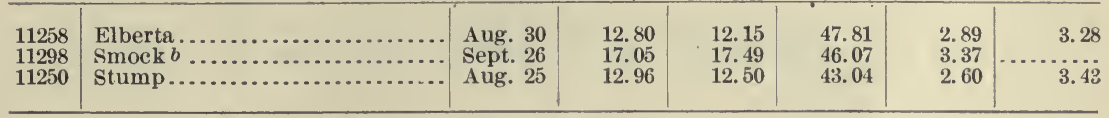

COMPARISON OF THE TWO STAGES.

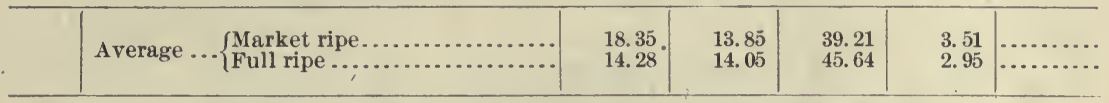

a Albuminoids, 1.86 ; amido bodies, 0.54 ; total nitrogenous bodies, 2.40 .

$b$ Albuminoids, 1.82 ; amido bodies, 0.374 ; total nitrogenous bodies, 2.19 .

The study of the later stages of the life history of the peach only tends to emphasize these changes. Thus in Table $\mathrm{V}$ we find that between the periods of market ripeness and full ripeness the percentage of niarc decreases from 18.35 to 14.28 per cent and the percentage of sugar increases from about 53 to practically 60 per cent.

As has been stated before, the absolute changes (as distinguished from relative changes) in the composition of growing fruit can only te determined from the expression of the results in terms of grams per individual, in this case in grams per peach. In Tables VI and VII the results given in the preceding tables have been so expressed. From Table VI it is apparent that the flesh of the peach increases rapidly, being about eleven times heavier at the date of market ripeness than at the date of the June drop. On the other hand, the increase in the weight of the stone is relatively small. The kèrnel almost doubles its weight between the time of the June drop and the time of the hardening of the stone and after that its weight does not appreciably change. 
STUDIES ON PEACHES.

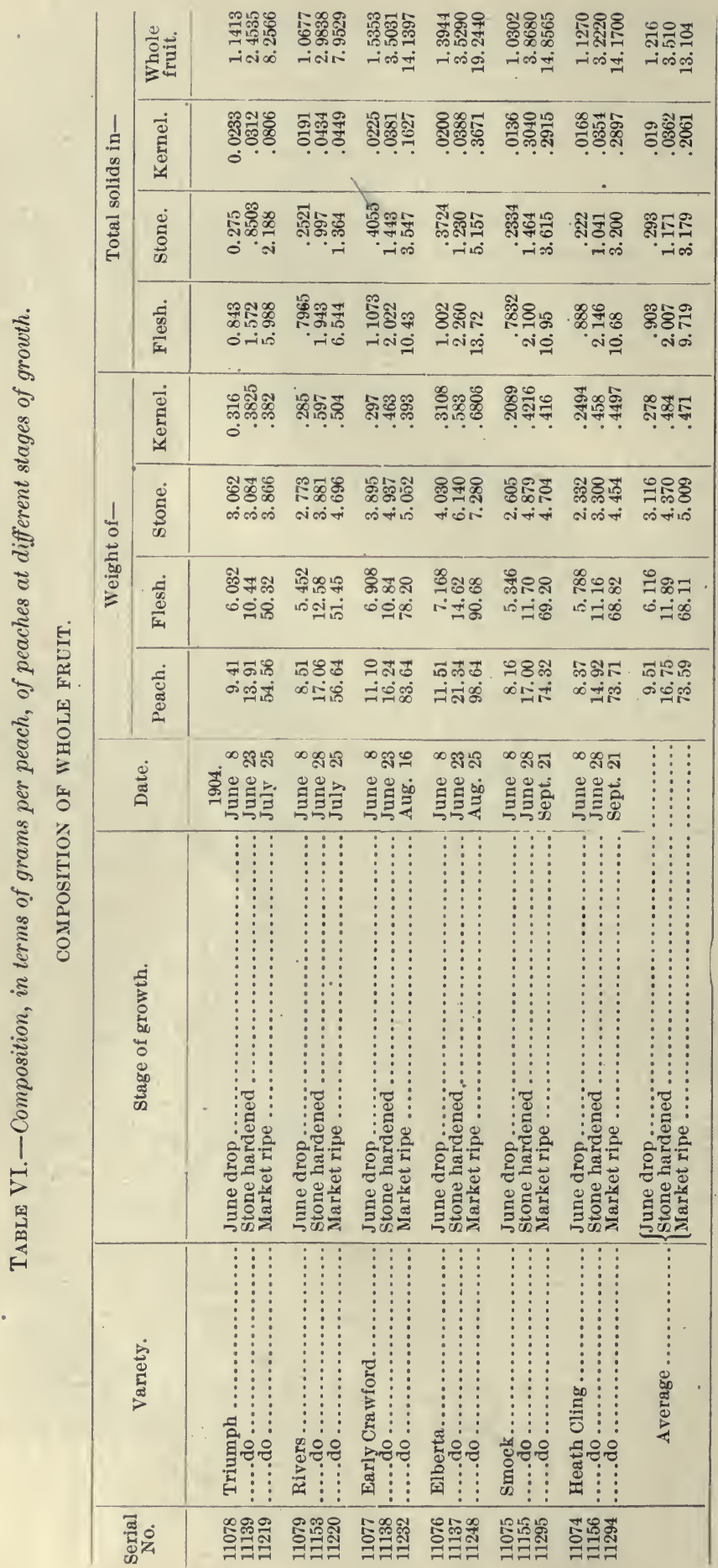


CHANGES IN COMPOSITION DURING GROWTH.

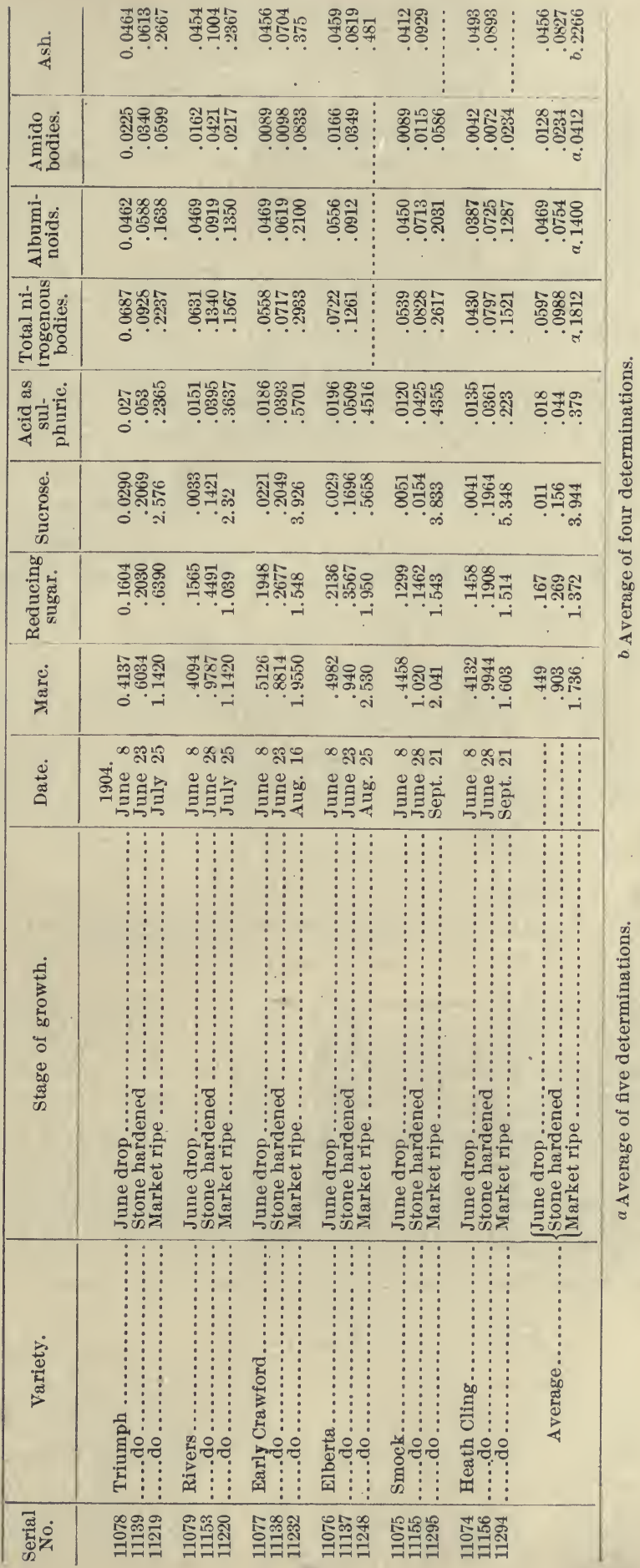


Since, as was noted in Tables II and III, the per cent of solids and of water in the flesh of the peach remains practically constant, the increase in the weight of solids must be proportional to the increase in the weight of the flesh of the peach. 'This is shown to be true in Table VI, the solids increasing from 0.903 gram per peach at the June drop to 9.719 grams at the time of market ripeness. Although the weight of the stone increased only slightly, the weight of the solids in the stone increased about tenfold between the June drop and the time of market ripeness. This is in keeping with the observation made on Table II that the percentage of solids in the stone increased, while, as shown in Table VI, the weight of the stone increases but slightly throughout the life history of the peach. The weight of solids in the kernel increases in somewhat the same proportion as the weight of solids in the stone. From Table VI it is also evident that the decrease in marc between the second and third periods at which the fruit was examined, apparent in Table II, is relative and not absolute, since the weight of marc in grams per peach is almost doubled between the time of the hardening of the stone and the period of market ripeness.

The weight of reducing sugar increases about eight times from the June drop to the time of market ripeness, and the increase in sucrose and acids is far greater than that of reducing sugar.

The various forms of nitrogenous substances all increase in absolute weight from the beginning to the end of the periods of observation. There is no apparent tendency for proteids to be decomposed into the simpler nitrogenous bodies, or to be built up in the growth of the peach. On the other hand, the relation between the amount of amido bodies and of proteids is fairly constant throughout the life history of the peach.

In Table VII, in which the composition of three varieties is given in terms of grams per peach from the market ripe to the fully ripe stages, it is apparent that the increase in weight is due, as stated before, not to the increase in water content alone, but also to an increase in solids, chiefly sugars. Both reducing sugar and sucrose increase during this period. On the other hand, the absolute weight of marc present is considerably decreased and the amount of acids also is slightly less.

TABLE VII.-Composition of peaches at market ripeness and at full ripeness.

[Grams per peach.]

COMPOSITION OF WHOLE FRUIT.

MARKET RIPE.

\begin{tabular}{|c|c|c|c|c|c|c|c|c|c|c|}
\hline \multirow[b]{2}{*}{$\begin{array}{c}\text { Serial } \\
\text { No. }\end{array}$} & \multirow[b]{2}{*}{ Variety. } & \multirow[b]{2}{*}{ Date. } & \multirow[b]{2}{*}{$\begin{array}{c}\text { Weight of } \\
\text { peach. }\end{array}$} & \multirow[b]{2}{*}{ Flesh. } & \multirow[b]{2}{*}{ Stone. } & \multirow[b]{2}{*}{ Kernel. } & \multicolumn{4}{|c|}{ Total solids in- } \\
\hline & & & & & & & Flesh. & Stone. & Kernel. & $\begin{array}{l}\text { Whole } \\
\text { fruit. }\end{array}$ \\
\hline $\begin{array}{l}11248 \\
11295 \\
11249\end{array}$ & $\begin{array}{l}\text { Elberta ........ } \\
\text { Smock ........ } \\
\text { Stump ........ }\end{array}$ & $\begin{array}{l}\text { Aug. } 25 \\
\text { Sept. } 21 \\
\text { Aug. } 25\end{array}$ & $\begin{array}{l}98.64 \\
74.32 \\
61.53\end{array}$ & $\begin{array}{l}90.68 \\
69.20 \\
56.14\end{array}$ & $\begin{array}{l}7.280 \\
4.704 \\
4.922\end{array}$ & $\begin{array}{c}0.6806 \\
.416 \\
.468\end{array}$ & $\begin{array}{c}13.72 \\
10.95 \\
9.516\end{array}$ & $\begin{array}{l}5.157 \\
3.615 \\
3.391\end{array}$ & $\begin{array}{r}0.3671 \\
.2915 \\
.2985\end{array}$ & $\begin{array}{l}\text { 19. } 244 \\
14.8565 \\
13.2055\end{array}$ \\
\hline
\end{tabular}


TABLE VII.-Composition of peaches at market ripeness and at full ripeness-Continued. COMPOSITION OF WHOLE FRUIT-Continued.

FULL RIPE.

\begin{tabular}{|c|c|c|c|c|c|c|c|c|c|c|}
\hline \multirow[b]{2}{*}{$\begin{array}{c}\text { Serial } \\
\text { No. }\end{array}$} & \multirow[b]{2}{*}{ Variety. } & \multirow[b]{2}{*}{ Date. } & \multirow[b]{2}{*}{$\begin{array}{l}\text { Weight of } \\
\text { peach. }\end{array}$} & \multirow[b]{2}{*}{ Flesh. } & \multirow[b]{2}{*}{ Stone. } & \multirow[b]{2}{*}{ Kernel. } & \multicolumn{4}{|c|}{ Total solids in- } \\
\hline & & & & & & & Flesh. & Stone. & Kernel. & $\begin{array}{l}\text { Whole } \\
\text { fruit. }\end{array}$ \\
\hline $\begin{array}{l}11258 \\
11298 \\
11250\end{array}$ & $\begin{array}{l}\text { Elberta } \ldots . . . \\
\text { Smock .......... } \\
\text { Stump ........ }\end{array}$ & $\begin{array}{l}\text { Aug. } 30 \\
\text { Sept. } 26 \\
\text { Aug. 25 }\end{array}$ & $\begin{array}{l}98.92 \\
86.67 \\
69.60\end{array}$ & $\begin{array}{l}90.32 \\
80.51 \\
63.76\end{array}$ & $\begin{array}{l}7.973 \\
5.66 \\
5.394\end{array}$ & $\begin{array}{l}0.623 \\
.5027 \\
.445\end{array}$ & $\begin{array}{l}13.95 \\
12.70 \\
11.17\end{array}$ & $\begin{array}{l}5.938 \\
4.347 \\
3.515\end{array}$ & $\begin{array}{l}0.368 \\
.3474 \\
.2568\end{array}$ & $\begin{array}{l}20.256 \\
17.394 \\
14.941\end{array}$ \\
\hline
\end{tabular}

COMPARISON OF THE TWO STAGES.

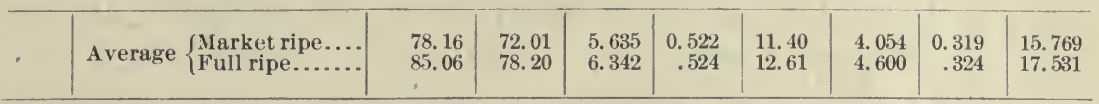

ANALYSIS OF FLESH.

MARKET RIPE.

\begin{tabular}{|c|c|c|c|c|c|c|c|c|c|c|}
\hline $\begin{array}{c}\text { Serial } \\
\text { No. }\end{array}$ & Variety. & Date. & Mare. & $\begin{array}{l}\text { Redu- } \\
\text { cing } \\
\text { sugar. }\end{array}$ & $\begin{array}{c}\text { Su- } \\
\text { crose. }\end{array}$ & $\begin{array}{l}\text { Acid as } \\
\text { sul- } \\
\text { phuric. }\end{array}$ & $\begin{array}{l}\text { Total } \\
\text { nitrog- } \\
\text { enous } \\
\text { bodies. }\end{array}$ & $\begin{array}{c}\text { Albu- } \\
\text { mi- } \\
\text { noids. }\end{array}$ & $\begin{array}{l}\text { Amido } \\
\text { bodies. }\end{array}$ & Ash. \\
\hline 11248 & Elberta ....... & Aug. 25 & 2. 530 & 1. 950 & 5.658 & 0.4516 & & & & 0.481 \\
\hline 11295 & Smock ......... & Sept. 21 & 2.041 & 1.543 & 3.833 & .4355 & 0.2617 & 0.2031 & 0.0586 & ........ \\
\hline
\end{tabular}

FULL RIPE.

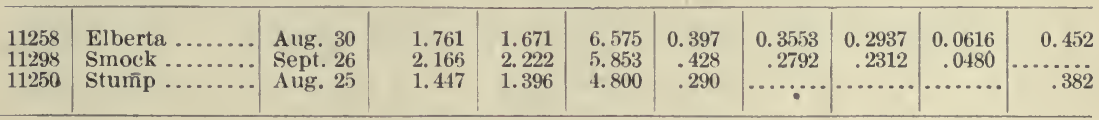

COMPARISON OF THE TWO STAGES.

\begin{tabular}{|c|c|c|c|c|c|c|c|c|c|c|}
\hline 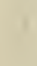 & Average & $\left\{\begin{array}{l}\text { Market ripe .... } \\
\text { Full ripe ...... }\end{array}\right.$ & $\begin{array}{l}2.085 \\
1.791\end{array}$ & $\begin{array}{l}1.578 \\
1.763\end{array}$ & $\begin{array}{l}4.457 \\
5.743\end{array}$ & $\begin{array}{r}0.399 \\
.372\end{array}$ & $\ldots \ldots$ & $\ldots \ldots$ & … & $\begin{array}{ll}\ldots \\
\ldots \ldots\end{array}$ \\
\hline
\end{tabular}

It is to be expected that with a quick-ripening fruit of this nature the time during which it is possible to study the ripening is much shorter than in the case of the slower ripening apples. Very soon after the full maturity of the peach is reached, and in many cases before that time, marked deterioration begins. The continued changes during storage, therefore, can not be studied as readily. In general it appears that many of the changes noted in apples are also true of the peach. The interesting questions attending the hydrolization of starch do not arise in the study of the peach, as starch only occurs in the peach in the two early stages of development and then in very small quantities.

From the beginning of the life history of the peach both reducing sugar and sucrose increase in weight. As the peach can not be stored for any great length of time after ripeness it is difficult to ascertain whether after full maturity, and especially after picking, sucrose ceases to form; and whether, when formed, it is rapidly converted into reducing sugar as in the case of the apple. 


\section{EFFECT OF STORAGE ON THE COMPOSITION OF PEACHES.}

The effects of three kinds of storage on the composition of peaches were studied, the fruit being stored at the time of market ripeness: First, at the ordinary room temperature in the summer time, the temperature ranging from $25^{\circ}$ to $30^{\circ} \mathrm{C}$. $\left(77^{\circ}\right.$ to $86^{\circ} \mathrm{F}$.), the results being recorded in Table VIII; second, in cold storage at $0^{\circ} \mathrm{C} .\left(32^{\circ} \mathrm{F}.\right)$, (see Table IX); third, in an ordinary refrigerator at a temperature of from $12^{\circ}$ to $15^{\circ} \mathrm{C}$. $\left(53.6^{\circ}\right.$ to $59^{\circ} \mathrm{F}$.), (see Table X). In all forms of storage the weight of the peaches decreased. This loss in weight was not entirely due to evaporation of water, for a diminution of solids in the flesh occurs in all cases.

In certain respects the changes in composition during storage suggest the changes that take place in apples under similar conditions. Unfortunately the experiments could not be prolonged sufficiently to follow these changes through as wide a range as is possible in the case of apples. The peach is short lived and at best remains in good condition, in fact remains alive, but a comparatively short period of time, whereas the apple may be kept for months, or even for a couple of years, in such condition that the cells are apparently able to perform their natural functions, though to a somewhat diminished extent.

The nature of the peach changes obviously even within two or three days at summer heat and its life can be prolonged only by reducing the temperature quickly after picking. It is apparent that the gain in reducing sugar to a large extent compensates for the loss in weight of sucrose, and the total loss of invert sugar is comparatively small. At the same time the loss in weight of marc can not be accounted for by the figures obtained in this experiment. It is probable that this loss is largely occasioned by the conversion of the insoluble pectin bodies into soluble pectins which, while they were a part of the mare of the peach, were not determined separately. Therefore we might expect the weight of the undetermined matter to increase somewhat proportionally with the disappearance of the marc. On the contrary, a decided decrease of undetermined matter has occurred. This can only be accounted for by the loss in total solids, and it is suggested that this loss is probably partly due to the consumption of invert sugar in the respiration of the peach, and that a portion of the marc may be converted into sugar in the life processes of the fruit. At the same time it seems possible that some of the pectin bodies may be consumed in the respiration. It is also possible that a portion of the loss in marc may be explained by the following fact: When after storage the sample was partially decayed and it became necessary to cut away the rotten parts, the proportion of skin sacrificed was probably relatively greater than that of the flesh, the skin being notably richer in marc than the flesh. 
The weight of the stone before and after storage was determined in only one case, in which practically no change in weight of total solids occurred. Whatever conclusions are drawn from the results of storage therefore depend on the assumption that this variety was typical of all in that respect-that is, that no loss in solids in the stone occurred in storage. This conclusion is probably justifiable. In the peaches stored at room temperature (Table VIII) the actual weight of marc decreased in all samples except the Heath Cling. The actual weight of reducing sugar increased in four varieties and decreased in two. The actual weight of sucrose increased in two varieties and decreased in four. The total sugars, calculated as invert, increased in two varieties and decreased in four. Owing to the small amount of acids and nitrogenous products present the actual weight of the increase and decrease of these substances is not sufficient to materially influence the results obtained by ignoring these bodies. Since it was found impossible to make the analysis as complete as was desired, some of the determinations of acids and nitrogenous bodies were omitted and an approximation of the undetermined material was obtained by assuming that the weight of acids and nitrogenous bodies per peach did not change. This assumption is doubtless not entirely correct, but the error caused by it can not be sufficient to materially affect the figures given for undetermined matter. In all cases, except that of the Early Crawford, the actual weight per peach of undetermined matter materially decreased.

Owing to the nature of the different varieties, they were kept in storage for different lengths of time, and therefore it becomes necessary to reduce the results to a given basis in order to make a comparison. This has been done by determining the loss per peach of each constituent for one day and dividing this loss, expressed in grams, by the average weight of solid matter in the flesh per peach at the beginning of the storage. On this basis the average loss in common storage was 3.117 per cent of solids, 1.751 per cent of marc, 1.778 per cent of sucrose, 0.271 per cent of total sugar (expressed as invert sugar), and 1.120 per cent of undetermined matter.

As would be expected, the peaches stored at the temperature of $32^{\circ} \mathrm{F} .\left(0^{\circ}\right.$ C.) changed much more slowly in their composition than those stored at room temperature, and in cold storage (Table IX) it was possible to preserve the samples for a much longer time than in the experiment previously described. The duration of the cold storage varied from twenty-eight to sixty-three days. However, the period during which the peaches could be so preserved, as stated before, was much less than in the case of apples. At the end of three or four weeks the flesh of the peach may begin to discolor and the flavor often becomes greatly impaired, especially if the atmosphere of the warehouse is impure. 
STUDIES ON PEACHES.

\begin{tabular}{|c|c|c|c|c|c|c|c|c|c|c|c|}
\hline & 造 & \begin{tabular}{l} 
ॠ \\
\hdashline \\
\hdashline
\end{tabular} & & 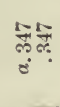 & & 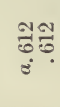 & & ర్థึ่ง & 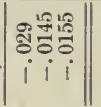 & ํํำ & 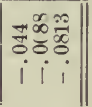 \\
\hline & 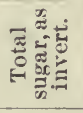 & $\begin{array}{l}\text { 苞菅 } \\
\text { ஸ் }\end{array}$ & 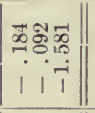 & 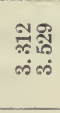 & 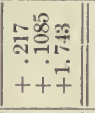 & 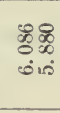 & $\left|\begin{array}{ccc}0 & 0 \\
0 & 0 & 0 \\
\hdashline & 0 & 0 \\
1 & 1 & 1 \\
1 & 1 & 1\end{array}\right|$ & 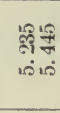 & 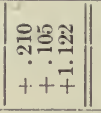 & 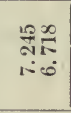 & 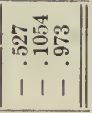 \\
\hline & 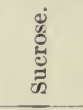 & 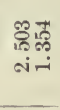 & 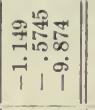 & 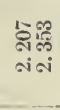 & 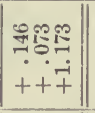 & 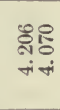 & 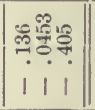 & 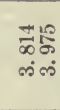 & 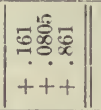 & 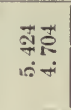 & 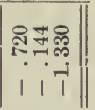 \\
\hline & 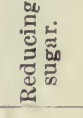 & ํํำ & 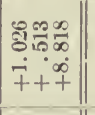 & 象商 & 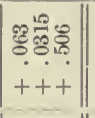 & 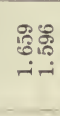 & 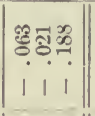 & $\begin{array}{l}\text { \$ิธ్టై } \\
\text { - }\end{array}$ & 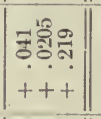 & 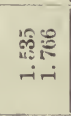 & 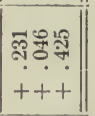 \\
\hline & 苞 & 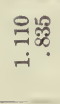 & 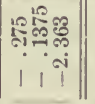 & 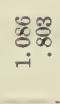 & 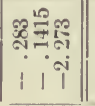 & $\begin{array}{l}\text { \%8\% } \\
\text { i. } \\
\text { i- }\end{array}$ & 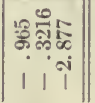 & 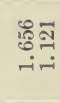 & 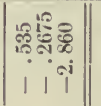 & 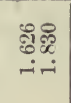 & 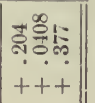 \\
\hline 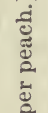 & 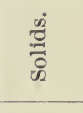 & 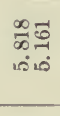 & 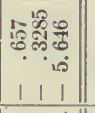 & 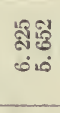 & 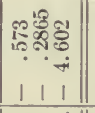 & 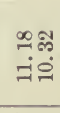 & 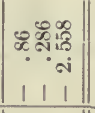 & 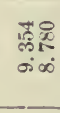 & 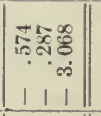 & 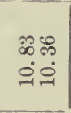 & 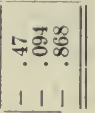 \\
\hline हूँ & $\frac{\dot{d}}{\frac{\tilde{g}}{\sqrt{u}}}$ & 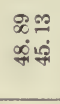 & $\begin{array}{ll}0 \infty \\
0 \infty \\
\infty \rightarrow-1 \\
1 \\
1\end{array}$ & $\begin{array}{l}\vec{\sigma} \\
\infty \\
\alpha \in \sigma\end{array}$ & 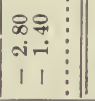 & 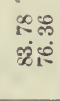 & 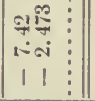 & 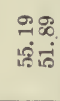 & 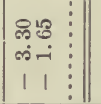 & $\begin{array}{l}88 \\
88 \\
80\end{array}$ & $\begin{array}{cc:}\infty & 0 \\
0 & \ddots \\
10 & -1 \\
1 & 1 \\
\vdots\end{array}$ \\
\hline & 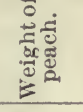 & 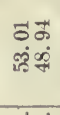 & $\begin{array}{c:c}5 & \vdots \\
& \vdots \\
& \vdots \\
1 & \vdots\end{array}$ & $\begin{array}{l}\infty 80 \\
\infty 8 \\
\text { : }\end{array}$ & \begin{tabular}{lll||}
$\infty$ & $\vdots$ \\
$\infty$ & $\vdots$ \\
$\infty$ & $\vdots$ \\
1 & $\vdots$
\end{tabular} & $\begin{array}{l}80 \\
80.0 \\
800\end{array}$ & 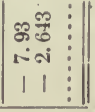 & 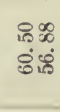 & 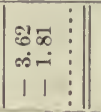 & 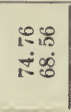 & 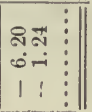 \\
\hline & 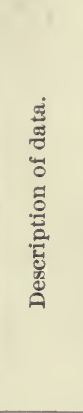 & 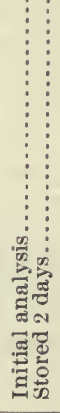 & 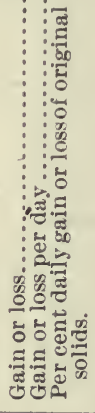 & 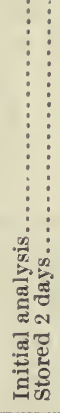 & 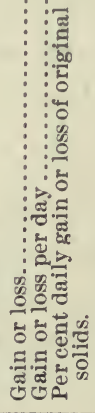 & 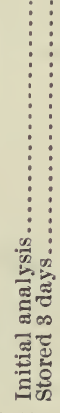 & 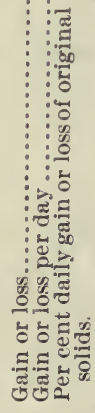 & 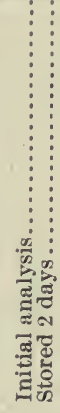 & 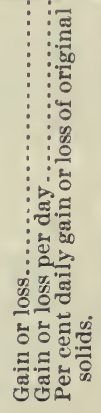 & 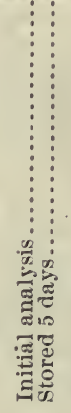 & 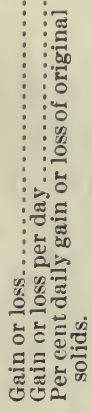 \\
\hline & 悹 & 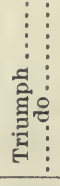 & & 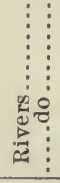 & 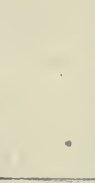 & 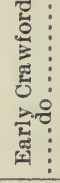 & & 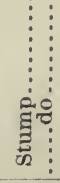 & & 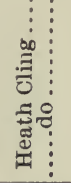 & \\
\hline & 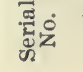 & 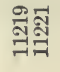 & & จ్స్ิ్ㅠ & & 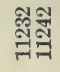 & & 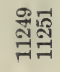 & & 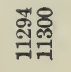 & \\
\hline
\end{tabular}

\begin{tabular}{|c|c|c|c|c|c|c|c|c|c|c|}
\hline 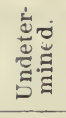 & . & 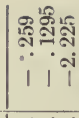 & $\begin{array}{l}\text { जొగ } \\
\text { जิ }\end{array}$ & 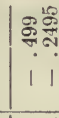 & & & & & & - \\
\hline 章 & 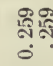 & & & & & & & & & \\
\hline
\end{tabular}

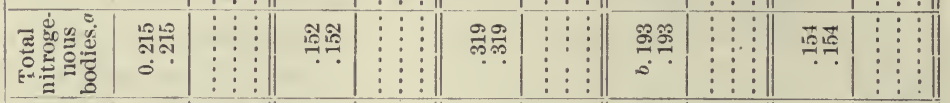




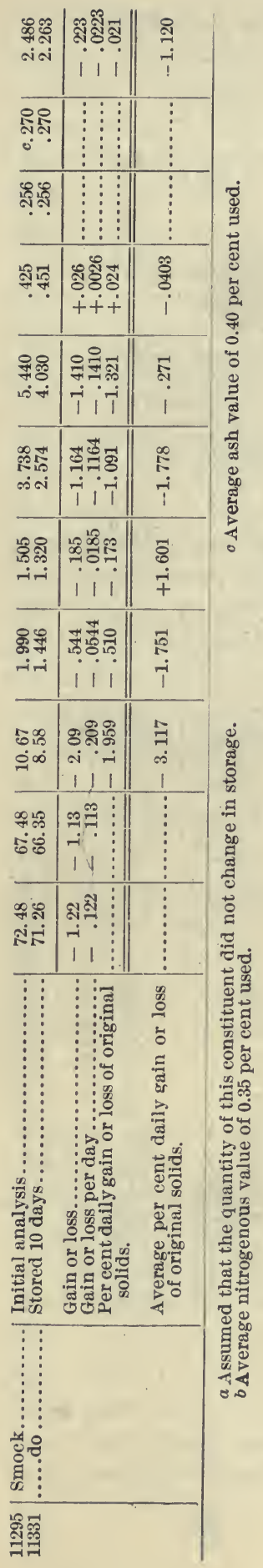




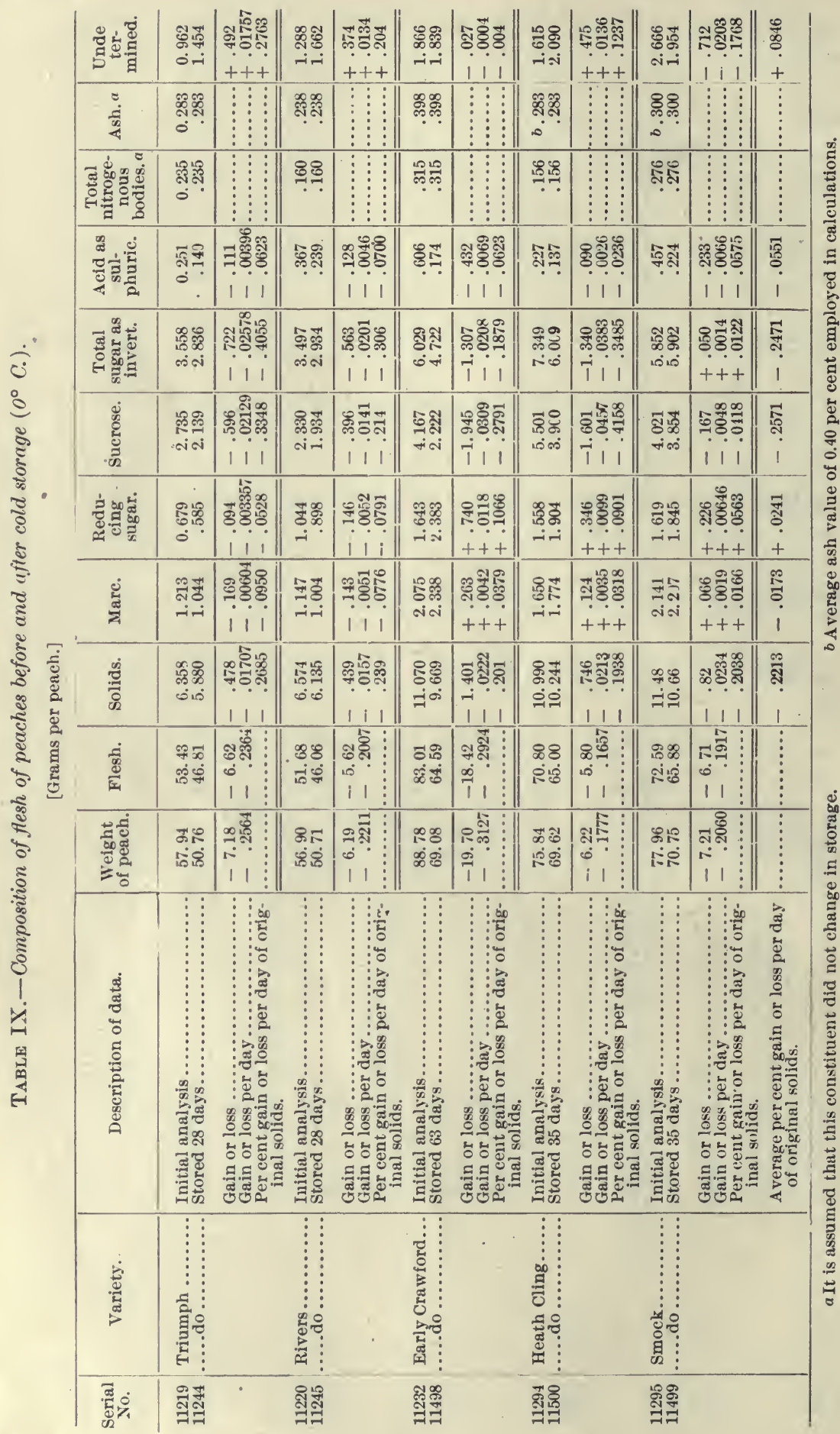


Of the peaches in cold storage, three varieties increased in the weight of marc and two decreased. The weight of reducing sugar increased in three varieties, the same three that increased in marc, and also decreased in the other two. The weight of sucrose decreased in every case. The weight of total sugar as invert increased in one case and decreased in four. The acids decreased in every case. The undetermined matter increased in three varieties and decreased in two.

Considering the average change in composition in the peaches preserved in cold storage, determined in the same way as in the case of peaches stored at room temperature, there is shown a loss of 0.221 per cent of solids, 0.017 per cent of mare, 0.247 per cent of total sugar expressed as invert, and 0.055 per cent of acids. Here, as in common storage, the weight of sucrose decreased and the weight of reducing sugar slightly increased. The increase in reducing sugar as compared with the decrease in weight of sucrose, however, was not as great relatively as in the case of the peaches in common storage, and the decrease in weight of marc as compared with the loss in weight of total solids and with the loss in weight of sucrose is much less than in the case of peaches stored in common storage. In common storage the loss of marc, expressed in percentage of the total solids of the peach, was over six times as great as the loss of total sugar, whereas in cold storage the loss in marc, expressed in the same terms, is only about one-fifteenth of that of total sugar.

Thus it is seen that the changes in composition of the peach that occur in cold storage appear to differ considerably from those occurring at the common temperature, the loss of mare being very much less and the loss of sugars somewhat less in the peaches preserved in cold storage than in those stored at ordinary temperatures. Further, the amount of undetermined matter, which must include among other things those pectoses which in the storage of the peaches are converted into soluble pectin bodies, has considerably increased in the peaches preserved in cold storage and markedly decreased in those stored at ordinary temperatures.

In addition to the peaches stored at ordinary room temperatures and those preserved in cold-storage warehouses three varieties were stored for periods varying from eight to ten days in an ordinary refrigerator at a temperature of from $12^{\circ}$ to $15^{\circ} \mathrm{C}$. $\left(53.6^{\circ}\right.$ to $59^{\circ} \mathrm{F}$.). These peaches, as in the other two experiments, showed in all cases a loss of total solids (Table $\mathrm{X}$ ). In one case there was a gain in marc, while with two varieties the weight of marc decreased. In all cases the weight of reducing sugar, sucrose (and of course of total sugars), and of acids decreased. With all three varieties there was an increase in the weight of undetermined matter. 


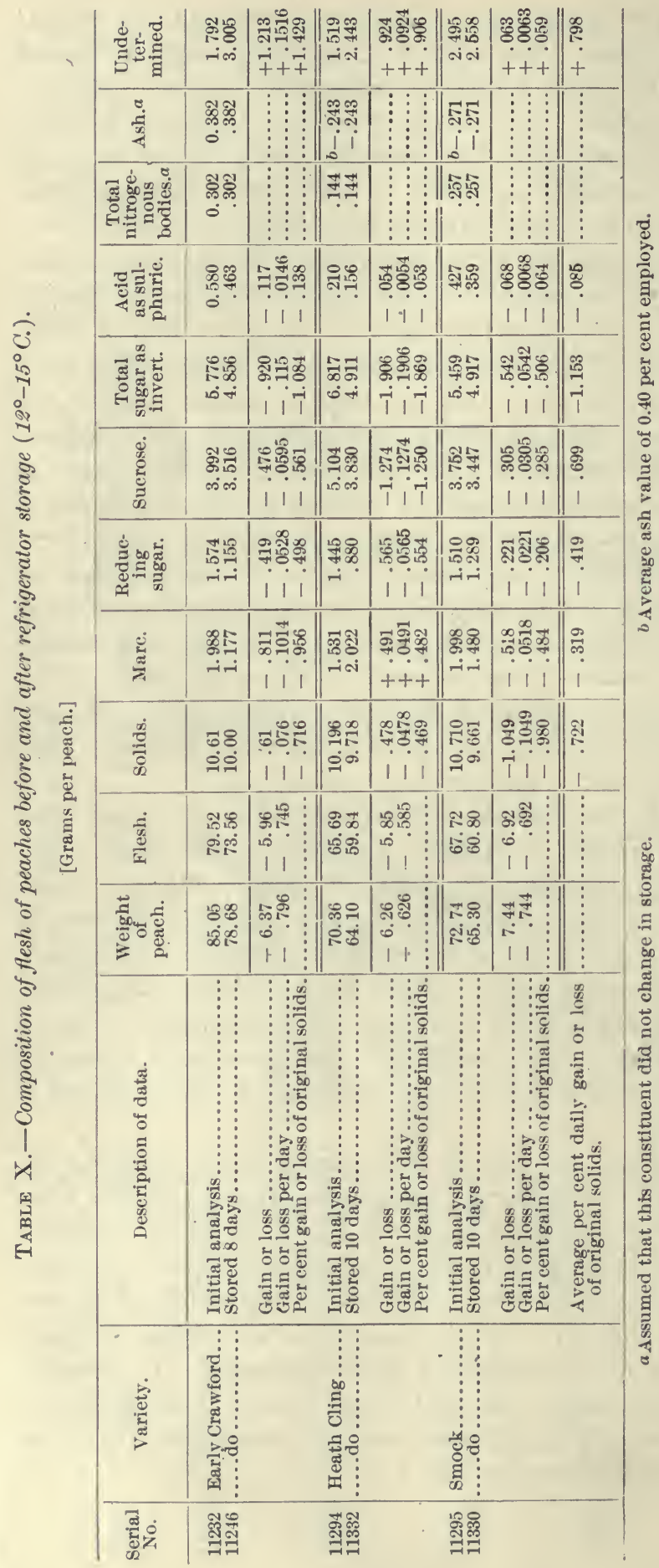


In general the changes in composition which occurred in the peaches kept in the refrigerator were intermediate between those that took place in common storage and in cold storage. This is true of the loss of solids, the loss of marc, and the loss of sucrose. The result with the reducing sugar is unexpected. In this determination an actual loss occurred with the refrigerator peaches, while a gain was found both with those preserved in cold storage and those in common storage. As a result of this the loss of total sugars was much greater in the refrigerator than in either of the other forms of storage. The loss of acid also was greater in the refrigerator than in either of the other forms of storage.

TABLE XI.-Comparison of average daily changes in peaches stored under various conditions.

[Percentage based on total solids of original sample.]

\begin{tabular}{|c|c|c|c|c|c|c|c|c|}
\hline Kind of storage. & $\begin{array}{l}\text { Time of } \\
\text { storage. }\end{array}$ & Solids. & Mare. & $\begin{array}{l}\text { Redu- } \\
\text { cing } \\
\text { sugar. }\end{array}$ & Sucrose. & $\begin{array}{l}\text { Total } \\
\text { sugar as } \\
\text { invert. }\end{array}$ & $\begin{array}{l}\text { Acid as } \\
\text { sul- } \\
\text { phuric. }\end{array}$ & $\begin{array}{l}\text { Undeter- } \\
\text { mined. }\end{array}$ \\
\hline $\begin{array}{l}\text { Common }\left(25^{\circ}-30^{\circ} \text { C. }\right) \ldots \ldots \\
\text { Cold }\left(0^{\circ} \text { C. }\right) \\
\text { Refrigerator }\left(12^{\circ}-15^{\circ} \text { C. }\right) \ldots\end{array}$ & $\begin{array}{r}\text { Dayys. } \\
2-10 \\
28-63 \\
8-10\end{array}$ & $\begin{array}{l}\text { Per cent. } \\
-3.117 \\
-.2213 \\
-.722\end{array}$ & $\begin{array}{l}\text { Per cent. } \\
-1.751 \\
-.0173 \\
-.319\end{array}$ & $\begin{array}{l}\text { Per cent. } \\
+1.601 \\
+.0241 \\
-.419\end{array}$ & $\begin{array}{l}\text { Per cent. } \\
-1.778 \\
-.2571 \\
-.699\end{array}$ & $\begin{array}{l}\text { Per cent. } \\
-0.271 \\
-.2471 \\
-1.153\end{array}$ & $\begin{array}{c}\text { Per cent. } \\
-0.0403 \\
-.0551 \\
-.085\end{array}$ & $\begin{array}{c}\text { Per cent. } \\
-1.120 \\
+.0846 \\
+.798\end{array}$ \\
\hline
\end{tabular}

In the discussion of the storage of peaches up to this point we have considered only peaches taken at the period of market ripeness. In addition to this, peaches were taken for the study of the effect of storage on their composition at earlier dates in their development. In Table XII are given the results of the analysis of very green peaches stored in the refrigerator at a temperature of from $12^{\circ}$ to $15^{\circ} \mathrm{C}$. $\left(53.6^{\circ}\right.$ to $59^{\circ} \mathrm{F}$.). These peaches were picked and the experiment begun just after the June drop. It is noticeable that the percentage of solids and of sucrose increased during this period (with the one exception of sucrose in the case of the Switzerland variety), while the percentage of reducing sugar decreased. The increase of solids of course can be explained by evaporation, and the decrease of reducing sugar may be due to the loss of that substance owing to its consumption in connection with the respiration of the fruit. The peaches were not weighed at the end of the period of storage, and for that reason these results can not be given in the terms of weight per peach. 
TABLE XII.-Composition of flesh of peaches stored in refrigerator for seven days from time of June drop.

[Percentage basis.]

\begin{tabular}{|c|c|c|c|c|c|c|c|}
\hline $\begin{array}{l}\text { Serial } \\
\text { No. }\end{array}$ & Variety. & Date. & $\begin{array}{c}\text { Weight of } \\
\text { peach. }\end{array}$ & Solids. & Sucrose. & $\begin{array}{l}\text { Reducing } \\
\text { sugar. }\end{array}$ & $\begin{array}{l}\text { Total } \\
\text { sugar as } \\
\text { invert. }\end{array}$ \\
\hline $\begin{array}{l}11079 \\
11116\end{array}$ & 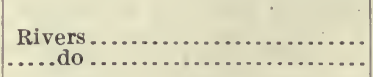 & $\begin{array}{l}\text { 1904. } \\
\text { June } 8 \\
\text { June } 15\end{array}$ & $\begin{array}{r}\text { Grams. } \\
8.51 \\
\ldots .\end{array}$ & $\begin{array}{r}\text { Per cent. } \\
14.61 \\
19.01\end{array}$ & $\begin{array}{r}\text { Per cent. } \\
0.06 \\
.21\end{array}$ & $\begin{array}{r}\text { Per cent. } \\
2.87 \\
1.72\end{array}$ & $\begin{array}{r}\text { Per cent. } \\
2.93 \\
1.94\end{array}$ \\
\hline $\begin{array}{l}11081 \\
11118\end{array}$ & $\begin{array}{l}\text { Salway } a . \ldots \ldots \\
\ldots \ldots \\
\ldots\end{array}$ & $\begin{array}{l}\text { June } 8 \\
\text { June } 15\end{array}$ & 7.81 & $\begin{array}{l}14.13 \\
17.55\end{array}$ & $\begin{array}{r}.32 \\
1.49\end{array}$ & $\begin{array}{r}2.10 \\
.73\end{array}$ & $\begin{array}{l}2.44 \\
2.30\end{array}$ \\
\hline $\begin{array}{l}11080 \\
11117\end{array}$ & 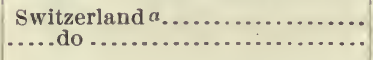 & $\begin{array}{l}\text { June } 8 \\
\text { June } 15\end{array}$ & $\begin{array}{r}8.73 \\
\cdots\end{array}$ & $\begin{array}{l}14.82 \\
17.09\end{array}$ & $\begin{array}{l}.21 \\
.19\end{array}$ & $\begin{array}{l}2.45 \\
1.36\end{array}$ & $\begin{array}{l}2.67 \\
1.56\end{array}$ \\
\hline
\end{tabular}

$a$ The variety could not be definitely ascertained, as no fruit from the selected tree approached maturity on account of Monilia.

Again, at the time of the hardening of the stone, four varieties of peaches were stored for eight days in an ice box, and the composition noted before and after. The results are given in Table XIII on the percentage basis and in Table XIV in terms of grams per peach. In this case there is an apparent loss in weight of solids, marc, sucrose, and total sugar, and a gain in weight of reducing sugar and in undetermined matter. On the whole the result of the storage at this temperature is very similar to that with the peaches stored in the ice box in a more mature condition.

TABLE XIII.-Composition of peaches stored in a refrigerator for eight days from the date of the hardening of the stone.

[Percentage basis.]

COMPOSITION OF WHOLE FRUIT.

\begin{tabular}{|c|c|c|c|c|c|c|c|c|}
\hline $\begin{array}{l}\text { Serial } \\
\text { No. }\end{array}$ & Variety. & Date. & $\begin{array}{l}\text { Weight } \\
\text { of peach. }\end{array}$ & Flesh. & Stone. & $\begin{array}{l}\text { Solids in } \\
\text { stone. }\end{array}$ & Kernel. & $\begin{array}{l}\text { Solids in } \\
\text { embryo. }\end{array}$ \\
\hline $\begin{array}{l}11153 \\
11188\end{array}$ & $\begin{array}{l}\text { Rivers...... } \\
\ldots \ldots \text { do } . . . .\end{array}$ & $\begin{array}{l}1904 . \\
\text { June } 28 \\
\text { July } 6\end{array}$ & $\begin{array}{r}\text { Grams. } \\
17.06 \\
16.81\end{array}$ & $\begin{array}{r}\text { Per cent. } \\
73.76 \\
73.50\end{array}$ & $\begin{array}{r}\text { Per cent. } \\
22.75 \\
23.78\end{array}$ & $\begin{array}{r}\text { Per cent. } \\
25.70 \\
29.05\end{array}$ & $\begin{array}{r}\text { Per cent. } \\
3.50 \\
2.73\end{array}$ & $\begin{array}{r}\text { Per cent. } \\
7.27 \\
9.28\end{array}$ \\
\hline $\begin{array}{l}11156 \\
11191\end{array}$ & 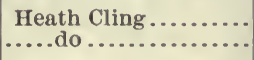 & $\begin{array}{l}\text { June } 28 \\
\text { July } 6\end{array}$ & $\begin{array}{l}14.92 \\
14.07\end{array}$ & $\begin{array}{l}74.80 \\
74.16\end{array}$ & $\begin{array}{l}22.12 \\
23.59\end{array}$ & $\begin{array}{l}31.55 \\
34.93\end{array}$ & $\begin{array}{l}3.07 \\
2.27\end{array}$ & $\begin{array}{r}7.72 \\
11.28\end{array}$ \\
\hline $\begin{array}{l}11155 \\
11190\end{array}$ & 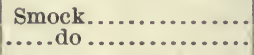 & $\begin{array}{l}\text { June } 28 \\
\text { July } 6\end{array}$ & $\begin{array}{l}17.00 \\
14.74\end{array}$ & $\begin{array}{l}68.84 \\
67.88\end{array}$ & $\begin{array}{l}28.70 \\
30.35\end{array}$ & $\begin{array}{l}30.00 \\
32.37\end{array}$ & $\begin{array}{l}2.48 \\
1.78\end{array}$ & $\begin{array}{r}7.21 \\
11.23\end{array}$ \\
\hline $\begin{array}{l}11154 \\
11189\end{array}$ & $\begin{array}{l}\text { Switzerland } a . . . . \\
\ldots \ldots \text { do }\end{array}$ & $\begin{array}{l}\text { June } 28 \\
\text { July } 6\end{array}$ & $\begin{array}{l}14.23 \\
13.61\end{array}$ & $\begin{array}{l}68.84 \\
68.60\end{array}$ & $\begin{array}{l}27.73 \\
28.75\end{array}$ & $\begin{array}{l}32.92 \\
33.50\end{array}$ & $\begin{array}{l}3.43 \\
2.67\end{array}$ & $\begin{array}{r}7.56 \\
10.79\end{array}$ \\
\hline
\end{tabular}

ANALYSIS OF FLESH.

\begin{tabular}{|c|c|c|c|c|c|c|c|c|c|c|}
\hline $\begin{array}{l}\text { Serial } \\
\text { No. }\end{array}$ & Variety. & Date. & Solids. & Mare. & $\begin{array}{l}\text { Redu- } \\
\text { cing } \\
\text { sugars. }\end{array}$ & $\begin{array}{c}\text { Total } \\
\text { sugar as } \\
\text { invert. }\end{array}$ & $\begin{array}{l}\text { Su- } \\
\text { crose. }\end{array}$ & $\begin{array}{c}\text { Acid as } \\
\text { sul- } \\
\text { phuric. }\end{array}$ & Ash. & $\begin{array}{l}\text { Pro- } \\
\text { tein. }\end{array}$ \\
\hline $\begin{array}{l}11153 \\
11188\end{array}$ & 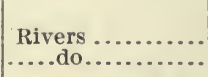 & $\begin{array}{l}1904 . \\
\text { June } 28 \\
\text { July } 6\end{array}$ & $\begin{array}{r}\text { Per ct. } \\
15.45 \\
16.36\end{array}$ & $\begin{array}{r}\text { Per ct. } \\
7.78 \\
7.42\end{array}$ & $\begin{array}{r}\text { Per ct. } \\
3.57 \\
2.42\end{array}$ & $\begin{array}{r}\text { Per ct. } \\
4.76 \\
2.76\end{array}$ & $\begin{array}{r}\text { Per ct. } \\
1.13 \\
.32\end{array}$ & $\begin{array}{c}\text { Per ct. } \\
0.314 \\
\ldots \ldots\end{array}$ & $\begin{array}{l}\text { Per ct. } \\
0.80\end{array}$ & $\begin{array}{r}\text { Per ct. } \\
1.07\end{array}$ \\
\hline $\begin{array}{l}11156 \\
11191\end{array}$ & $\begin{array}{l}\text { Heath Cling... } \\
\ldots . . . \text { do.......... }\end{array}$ & $\begin{array}{lr}\text { June } & 28 \\
\text { July } & 6\end{array}$ & & & $\begin{array}{l}1.71 \\
3.75\end{array}$ & & $\begin{array}{r}1.76 \\
.41\end{array}$ & $\begin{array}{r}.323 \\
. .3 \ldots\end{array}$ & .69 & $\begin{array}{l}.69 \\
\cdots\end{array}$ \\
\hline $\begin{array}{l}11155 \\
11190\end{array}$ & \begin{tabular}{|c|} 
Smock \\
$\ldots \ldots$
\end{tabular} & $\begin{array}{l}\text { June } 28 \\
\text { July } 6\end{array}$ & & $\begin{array}{l}8.72 \\
8.84\end{array}$ & $\begin{array}{l}1.25 \\
2.81\end{array}$ & $\begin{array}{l}2.64 \\
3.12\end{array}$ & $\begin{array}{r}1.32 \\
.29\end{array}$ & .363 & .79 & .70 \\
\hline $\begin{array}{l}11154 \\
11189\end{array}$ & $\begin{array}{l}\text { Switzerland } a \ldots . \\
\ldots \ldots \text { do............... }\end{array}$ & $\begin{array}{r}\text { June } \\
\text { July } 6\end{array}$ & $\begin{array}{l}17.63 \\
16.10\end{array}$ & $\begin{array}{l}7.92 \\
7.05\end{array}$ & $\begin{array}{l}2.33 \\
2.61\end{array}$ & $\begin{array}{l}3.64 \\
2.83\end{array}$ & $\begin{array}{r}1.24 \\
.21\end{array}$ & .370 & .98 & .79 \\
\hline
\end{tabular}

$a$ Variety not definitely determined, as fruit was destroyed by Monilia before reaching maturity. 
TABLE XIV.-Composition of peaches stored in a refrigerator for eight days from the date of the hardening of the stone.

[Basis of grams per peach.]

COMPOSITION OF WHOLE FRUIT.

\begin{tabular}{|c|c|c|c|c|c|c|c|c|}
\hline $\begin{array}{l}\text { Serial } \\
\text { No. }\end{array}$ & Variety. & Date. & $\begin{array}{l}\text { Weight. } \\
\text { of peach. }\end{array}$ & Flesh. & Stone. & Kernel. & $\begin{array}{l}\text { Solids in } \\
\text { stone. }\end{array}$ & $\begin{array}{l}\text { Solids in } \\
\text { embryo. }\end{array}$ \\
\hline $\begin{array}{l}11153 \\
11188\end{array}$ & 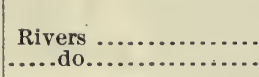 & $\begin{array}{l}\text { 1904. } \\
\text { June } 28 \\
\text { July } 6\end{array}$ & $\begin{array}{c}\text { Grams. } \\
17.06 \\
16.81\end{array}$ & $\begin{array}{c}\text { Grams. } \\
12.58 \\
12.36\end{array}$ & $\begin{array}{r}\text { Grams. } \\
3.88 \\
4.00\end{array}$ & $\begin{array}{r}\text { Grams. } \\
1.00 \\
1.16\end{array}$ & $\begin{array}{c}\text { Grams. } \\
0.60 \\
.46\end{array}$ & $\begin{array}{r}\text { Grams. } \\
0.043 \\
.043\end{array}$ \\
\hline $\begin{array}{l}11156 \\
11191\end{array}$ & $\begin{array}{l}\text { Heath Cling } . . . \ldots \ldots \\
\ldots \ldots \text { do.................... }\end{array}$ & $\begin{array}{l}\text { June } 28 \\
\text { July } 6\end{array}$ & $\begin{array}{l}14.92 \\
14.07\end{array}$ & $\begin{array}{l}11.16 \\
10.43\end{array}$ & $\begin{array}{l}3.30 \\
3.32\end{array}$ & $\begin{array}{l}1.04 \\
1.16\end{array}$ & $\begin{array}{l}.46 \\
.32\end{array}$ & $\begin{array}{l}.036 \\
.036\end{array}$ \\
\hline $\begin{array}{l}11155 \\
11190\end{array}$ & $\begin{array}{l}\text { Smock } \ldots \ldots \ldots \ldots \ldots \\
\ldots \ldots \ldots\end{array}$ & $\begin{array}{l}\text { June } 28 \\
\text { July } 6\end{array}$ & $\begin{array}{l}17.00 \\
14.74\end{array}$ & $\begin{array}{l}11.70 \\
10.01\end{array}$ & $\begin{array}{l}4.88 \\
4.47\end{array}$ & $\begin{array}{l}1.46 \\
1.45\end{array}$ & $\begin{array}{l}.42 \\
.26\end{array}$ & $\begin{array}{l}.030 \\
.029\end{array}$ \\
\hline $\begin{array}{l}11154 \\
11189\end{array}$ & 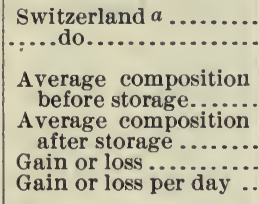 & $\begin{array}{l}\text { June } 28 \\
\text { July } 6\end{array}$ & $\begin{array}{r}15.65 \\
14.81 \\
-\quad .84 \\
-\quad .105\end{array}$ & $\begin{array}{r}11.31 \\
10.54 \\
-\quad .77 \\
-\quad .096\end{array}$ & $\begin{array}{r}3.93 \\
-\quad .07 \\
-.01\end{array}$ & $\begin{array}{r}1.27 \\
+.07 \\
+.01\end{array}$ & $\begin{array}{c}.49 \\
.35 \\
-.14 \\
-.018\end{array}$ & $\begin{array}{l}.037 \\
.037 \\
.000\end{array}$ \\
\hline
\end{tabular}

ANALYSIS OF FLESH.

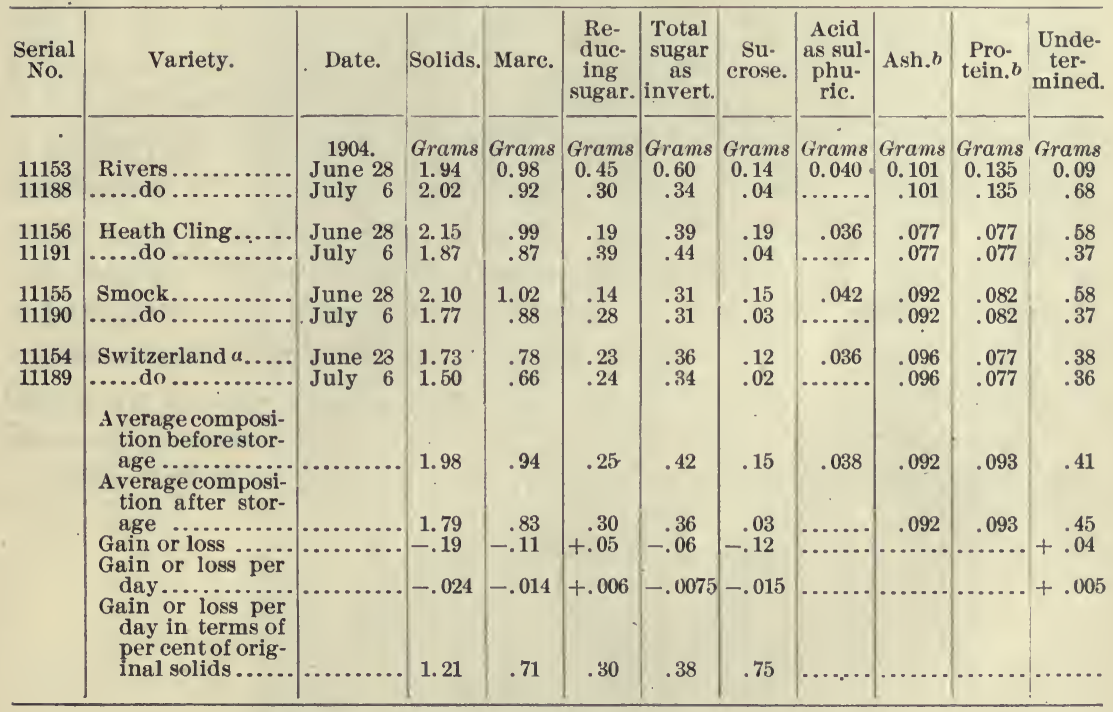

$a$ Variety not definitely determined.

$b$ Assumed that this constituent did not change in storage.

In the study of the ripening of the apple the writers called attention to the fact that the green apple had a tendency to mature much more rapidly than the ripe fruit. Even when the very green fruit was placed in storage it was noted that the starch disappeared much more rapidly with the correspondingly rapid hydrolysis into sugars than in the case of the ripe fruit, and in general the less mature the fruit the more rapid was the ripening. A little attention was given to this problem in the work on peaches, but the analyses seem to indi- 
eate that the rate of ripening of the green peach is not markedly more rapid than that of the more mature fruit.

Some problems have arisen in connection with this work, the solution of which must be attended with great difficulty and for which solution a more intimate knowledge must be obtained than is at present possessed of the constituents grouped together under the head of "undetermined." It is probable that an important part of the undetermined matter consists of pectin bodies, the insoluble pectins of the marc being, with the ripening of the peach or with the storage, converted into soluble pectins or other modifications of those bodies. The fact that the juice of the peach does not yield a jelly so readily as is the case with many other fruits would seem to indicate that the soluble pectins are of a different nature from those present in such fruits. The product is doubtless somewhat different from that present in the apple juice. At the same time it is still possible that further modifications of this group may exist in soluble form. There is apparently a tendency toward the hydrolization of sucrose with the formation of reducing sugar and the destruction of the reducing sugar in connection with the respiration of the fruit, yielding probably carbon dioxid and water. At the same time the increase of undetermined matter is usually sufficient to account for the decrease of the marc and to explain the latter by the assumption that it may be due to the conversion of insoluble pectin bodies into their soluble modifications. It is probable that the pectins may also be consumed to some extent in connection with the respiration of the peach or may be split up into simpler carbohydrate bodies. In this investigation it has only been attempted to outline very broadly the changes occurring in the maturity and storage of the peaches. It is hoped that in the near future some worker will find the opportunity to study some of the details whose mastery is essential to the thorough understanding of the problems here discussed. 





\section{DAY USE \\ RETURN TO DESK FROM WHICH BORROWED \\ LOAN DEPT.}

This book is due on the last date stamped

on the date to which renewediate

Renewed books are subject to immediate recall.

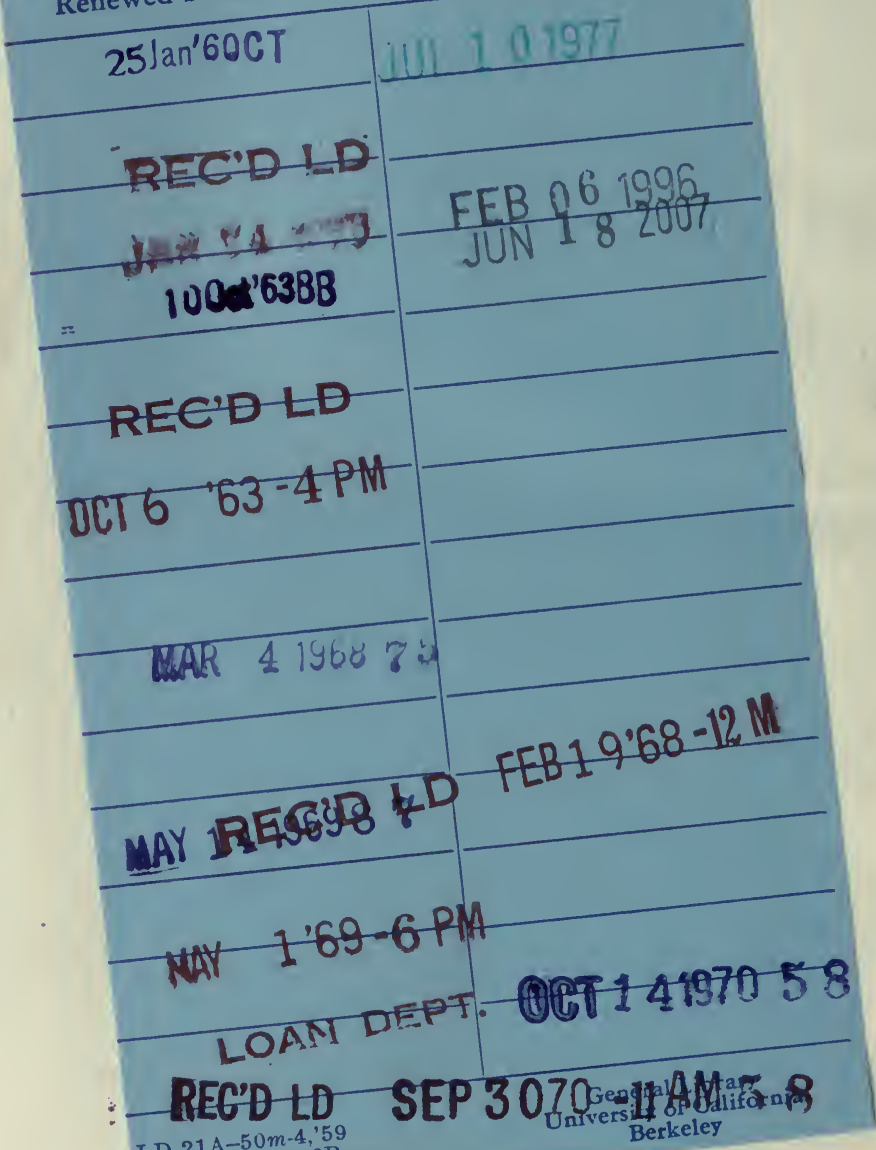


U. C. BERKELEY LIBRARIES

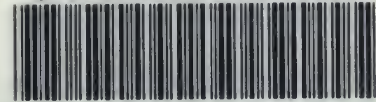

YU 18295

C051421368

LIBRARY USE

RETURN TO DESK FROM WHICH BORROWED

\section{LOAN DEPT.}

THIS BOOK IS DUE BEFORE CLOSING TIME ON LAST DATE STAMPED BELOW

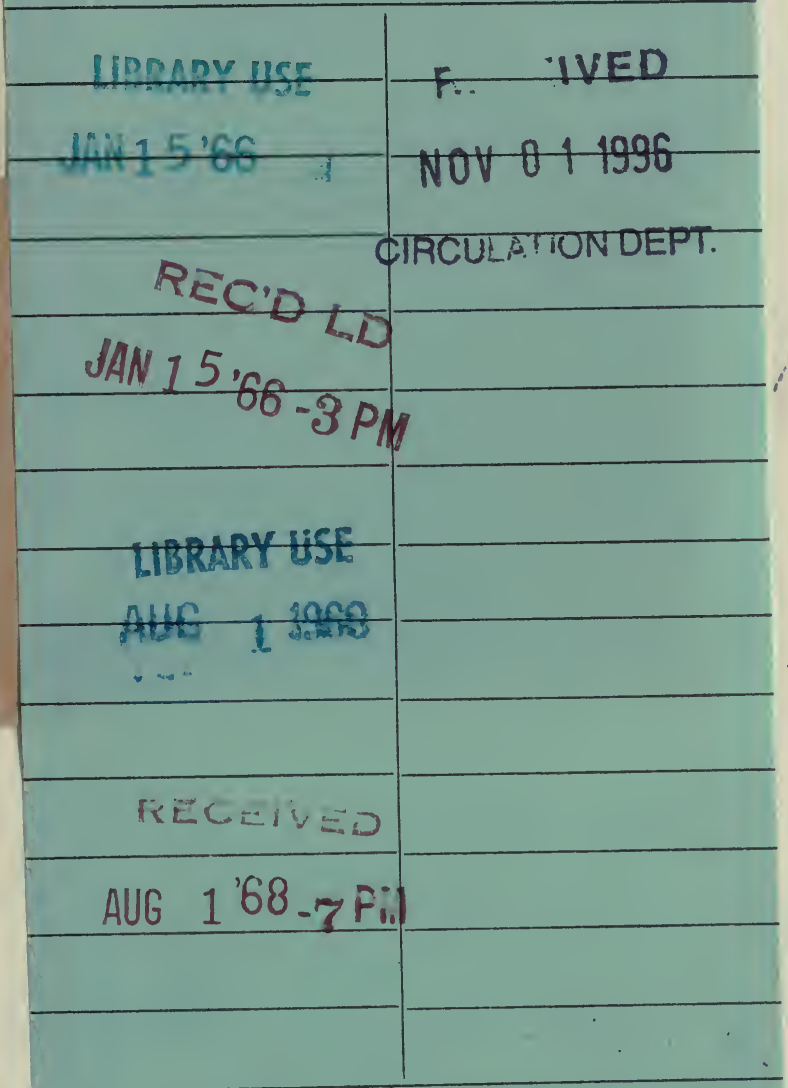

LD $62 \mathrm{~A}-50 m-2,64$

(E3494810) 9412A

General Library

University of California Berkeley 
